\title{
Disaster Risks of the Seven Filipino-Spanish Churches of the Diocese of Maasin, Philippines Disaster Risks ng Pitong Pilipino-Espanyol na Simbahan ng Diyosesis ng Maasin sa Pilipinas
}

\author{
Raffy Andrew G. Loreto ${ }^{1}$, Guiraldo C. \\ Fernandez, Jr. ${ }^{2}$, Leslie Anne L. Liwanag ${ }^{2}$, \\ and F.P.A. Demeterio III $^{3}$ \\ ${ }^{1}$ Department of Civil Engineering, Visayas State \\ University Baybay City, Philippines \\ ${ }^{2}$ Department of Liberal Arts and Behavioral \\ Sciences, Visayas State University Baybay City, \\ Philippines \\ ${ }^{3}$ Filipino Department, De La Salle University Manila, \\ Philippines \\ Correspondence: \\ raffyandrew.loreto@vsu.edu.ph
}

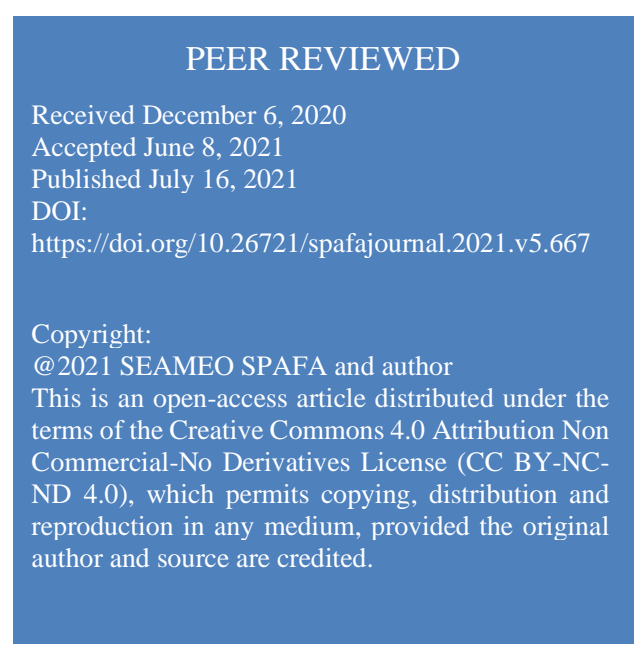

\begin{abstract}
In the Roman Catholic Diocese of Maasin, on the island of Leyte, Philippines, there remain today seven Filipino-Spanish churches that are made of stone, mortar and wood, ranging from almost four centuries to more than a century old. The Island of Leyte, as home to 22 active and dormant volcanoes, as exposed to the atmospheric disturbances from the Pacific Ocean, and as bisected by the Philippine Fault Line, is more at risk to extreme natural hazards than an average Philippine island. By looking at the interplay between the resistance/vulnerability of these churches on one hand, and the natural hazards threatening these churches on the other hand, this paper proffers mitigating recommendations to the primary stakeholders with the purview of increasing the resilience of these same churches. The data on the resistance/vulnerability of the said churches were gathered through rapid survey, while the data on natural hazards were gathered through existing hazard maps and web applications. The methodology laid out by this paper can be a useful initial step for the conservation of heritage structures in developing societies.
\end{abstract}

Sa Katoliko Romanong Diyosesis ng Maasin sa isla ng Leyte sa Pilipinas, kasalukuyang may pitong Pilipino-Espanyol na simbahang gawa sa bato, mortar, at kahoy na halos isa hanggang apat na siglo nang umiiral. Ang Isla ng Leyte ay tahanan ng 22 na aktibo at dormanteng bulkan na nakalantad sa mga atmosperikong alburuto mula sa Karagatang Pasipiko at nahahati pa sa ilalim ng fault line ng Pilipinas. Ilan lamang sa dahilan kung bakit maituturing na risk sa matitinding likas na panganib kumpara sa karaniwang isla sa Pilipinas. Kapag titingnan ang pagkikipagtalaban ng resistance/bulnerabilidad, kaakibat ang mga likas na inaasahang panganib (natural hazards) ng mga simbahan, mahalaga para sa papel na ito na magbigay ng mga rekomendasyon sa mga pangunahing stakeholder na makakabawas ng masamang epekto datapwat magpapalawak pa ng katatagan ng mga natukoy na simbahan. Sa pamamagitan ng rapid survey, kinalap ang mga datos hinggil sa resistance/bulnerabilidad ng mga simbahan, samantalang nilikom ang datos sa mga likas na inaasahang panganib sa pamamagitan ng mga umiiral na hazard maps at web applications. Maaaring maging kapaki-pakinabang ang metodolohiyang ginamit ng papel upang magsilbing 
inisyal na hakbang sa konserbasyon ng mga estrukturang pamana sa mga umuunlad pa lamang na lipunan.

Keywords: Heritage Structures, Diocese of Maasin, Filipino-Spanish Churches, Floods, Storm Surges, Volcanic Eruptions, Earthquakes, Storms | Mga Estrukturang Pamana, Diyosesis ng Maasin, Mga Pilipino-Espanyol na Simbahan, Baha, Daluyong, Pagputok ng Bulkan, Lindol, Bagyo

\section{Introduction}

The island of Leyte, located in Eastern Visayas, Philippines, is shared by three Roman Catholic arch/dioceses, namely: the Archdiocese of Palo, comprising the majority of the cities/towns of the province of Leyte; the Diocese of Maasin, comprising all the city/towns of the province of Southern Leyte plus six more city/towns in the province of Leyte; and the Diocese of Naval, which has its seat on the northern island province of Biliran but has four additional towns in the province of Leyte (see Figure 1). In the Diocese of Maasin, which is located at the south-western part of the island of Leyte, there remain today seven Filipino-Spanish churches that are made of stone, mortar, and wood that were built or rebuilt by the Jesuits, Augustinians, and the seculars from the Diocese of Cebu. Figure 1 enumerates the names of these Filipino-Spanish churches and points out their locations. 


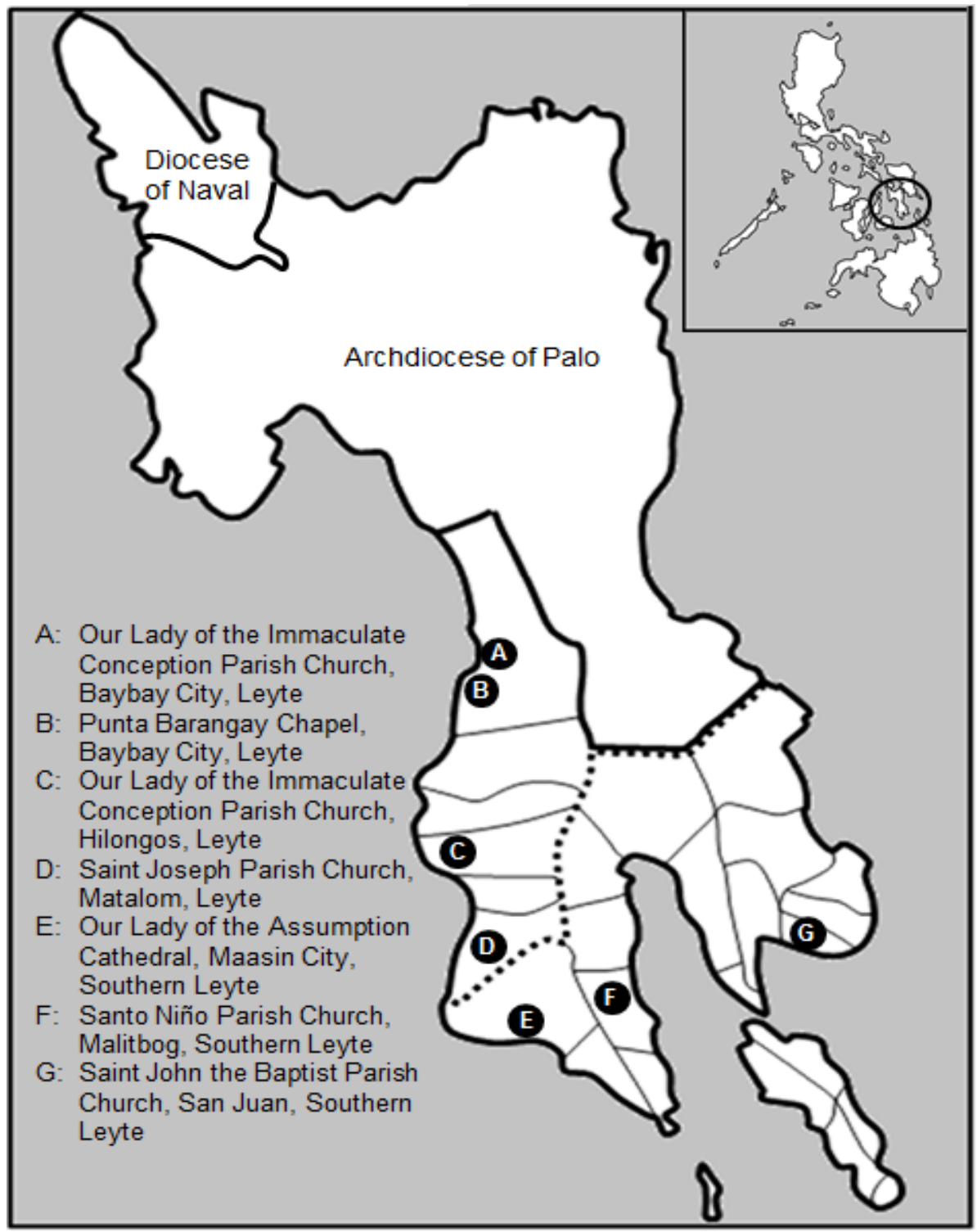

Fig. 1 Map of the Locations of the Seven Filipino-Spanish Churches of the Diocese of Maasin.

For the sake of brevity, this paper will refer to these churches as: Baybay Church (A), Punta Chapel (B), Hilongos Church (C), Matalom Church (D), Maasin Church (E), Malitbog Church (F), and San Juan Church (G). F.P.A. Demeterio, Guiraldo Fernandez and Leslie Anne Liwanag, in their book Cataloging and Baselining the Filipino-Spanish Churches of the Diocese of Maasin on the Island of Leyte, document or estimate the constructions of these churches as follows: Baybay Church, 1852; Punta Chapel, circa 1634-1650s; Hilongos Church, circa 1710-1754; Matalom Church, circa 18631884; Maasin Church, circa 1771-1780s; Malitbog Church, 1854; and San Juan Church, 1892 (Demeterio, Fernandez \& Liwanag 2020: 46, 10, 18, 68, 30, 55, \& 77).

\section{Statement of the Problem}

The Island of Leyte, as home to 22 active and dormant volcanoes, as exposed to the atmospheric disturbances from the Pacific Ocean, and as bisected by the Philippine Fault Line, is more at risk to extreme natural hazards than an average Philippine island. This paper grapples with the main problem, what are the risk profiles of these seven Filipino-Spanish churches against extreme natural hazards? This main problem is tackled by the following more specific sub-problems: 1) what are the resistance/vulnerability profiles of these churches that may be gathered though rapid assessment 
surveys?; 2) what are the natural multi-hazard threats against these churches that may be gathered from existing hazard maps and web applications?; 3) what are the risk profiles of these churches?; and 4) what mitigation recommendations can be proffered to the primary stakeholders of these churches so as to increase their resilience against the already mentioned natural multi-hazard threats?

\section{Significance of the Paper}

This paper is significant for heritage conservation practitioners in emphasizing that risks to any given heritage structure is an interplay between its resistance/vulnerability on one hand and the natural extreme hazards that threaten it on the other hand. The resilience of any given heritage structure can be increased by adopting mitigating measures. This paper is also significant in the sense that the methodology it lays out can be a useful initial step for the conservation of heritage structures in developing societies. The non-invasive rapid assessments used by this paper can be easily replicated by stakeholders of other heritage structures with the guidance of engineers and technicians. In the Philippines, where hazard maps and web applications are present, stakeholders of a good majority of heritage structures can replicate this paper's multi-hazard mapping.

On a more practical level this paper is significant in proffering mitigating recommendations to increase the resilience of the seven heritage churches at hand. The findings of this paper will allow the primary stakeholders of the said seven churches to prioritize their conservation efforts to achieve maximum effects. This paper will also raise the consciousness of the primary stakeholders for the need of more proactive efforts in conserving these same structures, as well as for periodic surveys of their resistance/vulnerability profiles. All of these seven heritage structures are used up to the present times as places of worship. A systematic study on how to increase the resilience of these structures can mobilize their worshipping stakeholders to support actual mitigating interventions. The risks and mitigating recommendations laid out by this paper could also catalyze the sectorally fragmented stakeholders to cooperate and synchronize their efforts for the sake of their heritage structures. This baseline study could also hopefully put an end to the sporadic initiatives of some stakeholders to inflict damages on the structural fabric of these churches as a consequence of their often-misguided desires to beautify and modernize these churches. This paper could also serve an eye opener on the part of the primary stakeholders on the need for more advanced and sophisticated resistance/vulnerability assessments of their heritage structures.

\section{Literature Review}

This paper was able to identify a handful of recent and relevant international studies on heritage structures and disaster risks. Bosher et al.'s 2019 "Dealing with Multiple Hazards and Threats on Cultural Heritage Sites: An Assessment of 80 Case Studies" is a review of some 80 case studies coming from 45 countries as gathered by a UNESCO International Training from 2006 to 2016 (Bosher et al. 2019). This identified earthquake, flood, fire, storm, and landslide as the top five hazards to heritage structures (Bosher et al. 2019). This paper also emphasized that, more often than not, there are multiple hazards threatening each heritage structure (Bosher et al. 2019). Bonazza et al.'s 2018 Safeguarding Cultural Heritage from Natural and Man-Made Disasters: A Comparative Analysis of Risk Management in the EU used the Sendai Framework for Disaster Risk Reduction 2015-2030 in comparatively critiquing cultural heritage risk management systems and practices of the 28 member states of the European Union (Bonazza et al. 2018). Among other things, this paper established how even in these relatively advanced countries cultural heritage is left out in risk management planning and strategies (Bonazza et al. 2018). Stanton-Geddes, Soz, and BonteGrapentin’s 2017 Promoting Disaster Resilient Cultural Heritage also used the Sendai Framework 
for Disaster Risk Reduction 2015-2030 in proffering the following pointers for the protection of cultural heritage: the establishment of appropriate laws, policies, and institutional frameworks; the continuous understanding of risks; the reduction of risks and building of capacities; and the preparation of post-disaster plans (Stanton-Geddes, Soz, and Bonte-Grapentin 2017).

Following Bosher et al., this paper explores multiple hazards and risks for each of the covered seven heritage structures. Deviating a little from Bosher et al., the multiple hazards examined by this paper are earthquakes, floods, storm surges, volcanoes, and storms, as hazards are highly contextualized to the specific locations of heritage structures. Following Bonazza et al. and StantonGeddes, Soz, and Bonte-Grapentin, this paper will use as its theoretical framework the Sendai Framework for Disaster Risk Reduction 2015-2030, as well as advocate for the mainstreaming of the inclusion of heritage structures in disaster risk management. Being a preliminary study on the Diocese of Maasin's seven heritage churches, this paper did not follow yet Stanton-Geddes, Soz, and Bonte-Grapentin in focusing too much on post-disaster plans.

There are a handful of studies on Philippine heritage structures that focused on specific natural hazards. Song, Galasso, and Garciano’s 2020 “Wind-Uplift Fragility Analysis of Roof Sheathing for Cultural Heritage Assets in the Philippines" focused on the interaction between typhoon winds and the non-engineered roofing systems of some eight heritage structures on the Island Province of Bohol, in the central part of the Philippines, with the intention forecasting the extent of damage and prioritizing intervention efforts. Sevieri and Galasso’s 2020 “Typhoon Fragility Analysis and Climate Change Impact Assessment of Filipino Cultural Heritage Asset Roofs" also focused on the interaction between typhoon winds and the non-engineered roofing systems this time of 25 heritage structures in Iloilo City, in the west central part of the Philippines, with the motivation of forecasting the extent of damage brought about by worsening atmospheric disturbances caused by climate change. Garciano et al.’s 2019 “Assessment of Strength Parameters of URM Blocks in Heritage Structures in the Philippines” comparatively analyzes the strengths of adobe, coralline limestone, and sandstone, the common type of stones used in Filipino-Spanish churches by using shear and flexure tests with the intension of understanding their capacity to withstand earthquakes. Yu et al.’s 2014 “Seismic Risk Assessment of Heritage Buildings in Iloilo City, Philippines” profiles the risks of some 29 heritage structures in Iloilo City against earthquake hazard with the aim of prioritizing intervention effort. In this paper rapid vulnerability assessment was used to profile the resistance/vulnerability of the 29 structures, while earthquake hazard was measured in terms of distance of the structure to the nearest fault line, seismic source type, and soil conditions.

There are also a handful of studies on Philippine heritage structures that focused on multiple natural and man-made hazards. Sevieri et al.'s 2019 “The CHeRiSH Project: Towards a Multilevel, MultiHazard Risk Assessment Framework for Cultural Heritage Assets in the Philippines” focused on two natural hazards, earthquake and typhoon, as it studied 25 heritage structures in Iloilo City. It used three levels of rapid resistance/vulnerability assessments that ranges from inspection from the sidewalk by a trained engineer to a highly detailed structural analysis of the building. D'Ayala et al.'s 2016 “Assessment of the Multi-Hazard Vulnerability of Priority Cultural Heritage Structures in the Philippines" focused on four natural hazards, earthquake, typhoon, flood, and storm surge, as it investigated on a Filipino-Spanish church in Dimiao, on the Island Province of Bohol (Sevieri et al. 2019). In profiling the earthquake risk, this paper used FaMIVE which was developed by D'Ayala and Speranza in the early 2000s in studying Italian heritage structures; in profiling the typhoon risk, this paper studied the interaction between roofing systems and strong winds; in profiling the combined flood and storm surge risk, this paper used data from Project NOAH (Sevieri et al. 2019). Yu, Oreta, Ibabao , and Hechanova’s 2013 “Supporting Local Initiatives in Preserving Heritage 
Buildings in Iloilo City (Philippines) through Risk Assessment” focused on three hazards, earthquake, typhoon and fire, as it examined 26 heritage structures in Iloilo City. In profiling the earthquake risk, this paper considered the structures' occupancy, soil type, building type and modifiers; in profiling the typhoon risk, this paper considered the roof characteristics, door and window characteristics, and the structures' elevation; and in profiling the fire risk, this paper considered the presence of flammable substances, explosive materials, combustible substances.

This paper expands the geographic scope of the Philippine literature beyond the island province of Bohol and Iloilo City, by studying seven heritage churches on the island of Leyte. This paper also expands the hazards that were analyzed by the Philippine literature by including volcanic hazards as well as by disaggregating flood and storm surge hazards based on the difference on the behavior of these two hydrological disturbances. This paper builds on Yu and Oreta's method in analyzing earthquake hazards. This paper utilizes Sevieri et al.'s (2019) first level of rapid resistance/vulnerability assessment, and follows their reliance on Project NOAH. This paper also builds on Yu, Oreta, Ibabao, and Hechanova's way of assessing typhoon resistance/vulnerability. This paper does not follow Yu, Oreta, Ibabao, and Hechanova's inclusion of fire hazard as this is something that cannot be easily profiled using the first level rapid resistance/vulnerability assessment of Sevieri et al.

\section{Methodology}

\section{Theoretical Framework}

The United Nations Development Programme (UNDP) defines "risks" as the interactions between "natural or human-induced hazards and vulnerable conditions" (United Nations Development Programme 2010:1). Disaster risk management might be a famous buzzword these days. But more often than not, this buzzword is applied only to individuals, communities, private homes, and not to heritage structures (Stanton-Geddes, Soz, \& Bonte-Grapentin 2017: 6; Bonazza et al. 2018: 9). The Sendai Framework for Disaster Risk Reduction 2015-2030, however, clearly stipulates that cultural heritage should be part of the scope of disaster risk management (2015:11, 15, \& 19). This paper will use as its theoretical framework the Sendai Framework for Disaster Risk Reduction 2015-2030 By understanding the interactions between the resistance/vulnerability of a given heritage structure and the multiple natural hazards that threaten it, it is possible not only to grasp the risk profile of such heritage structure, but also to formulate mitigating interventions to increase the structure's resistance and therefore to decrease its vulnerability, and consequently increase the resilience of the same structure. The ideal interrelations among heritage structures, resistance/vulnerability, natural disasters, risks, mitigations, and resilience are visually presented in figure 2. 


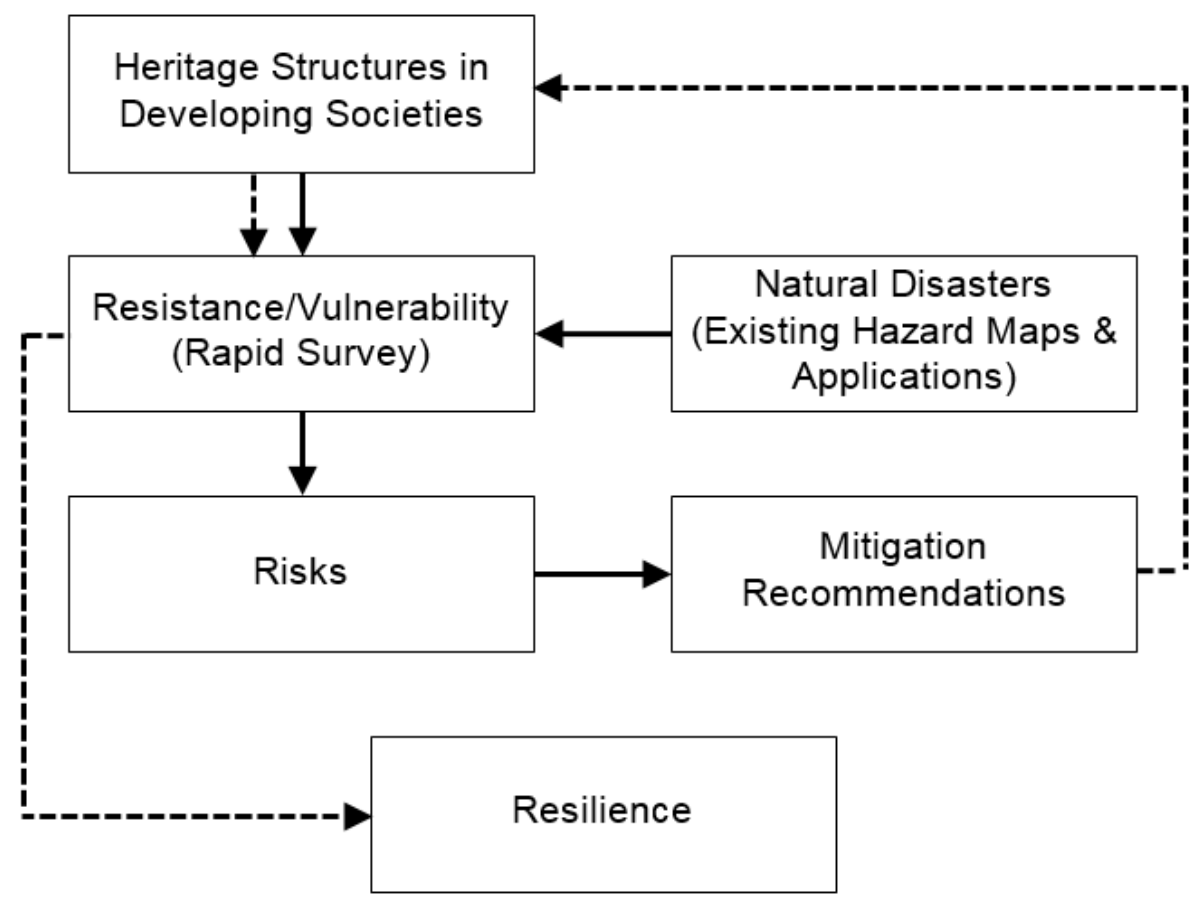

Fig. 2 Theoretical/Conceptual Interrelationship among Heritage Structures, Resistance/Vulnerability, Natural Disasters, Risks, Mitigations, and Resilience.

In developing societies, especially in peripheral regions, there can be very little interest among stakeholders and financial resources to start and fund elaborate baselining studies and conservation programs for heritage structures. But resistance/vulnerability assessments can be done with minimal funding through the use of rapid surveys. Similarly, the profiling of multi-hazard threats can be done with existing hazard maps and web applications. Fortunately, in the Philippines, a number of these hazard maps and web applications are easily accessible online. There are no reasons therefore why an initial study on the risk profiles of the seven heritage churches of the Diocese of Maasin cannot be undertaken. This initial study can hopefully serve as a baseline for some periodic iteration of assessments, risk profiling, and mitigation interventions either using the same low-cost methodology or some other more elaborate and invasive procedures.

Following this theoretical framework, the assessments and profiling undertaken by this paper are clustered into three: 1 ) resistance/vulnerability assessment, 2) multi-hazard assessment, and 3) multi-risk assessment.

\section{Resistance/Vulnerability Assessment}

The first cluster of assessments of this paper mapped out the vulnerabilities of the seven FilipinoSpanish churches through on-site rapid vulnerability assessments. Because this paper is an initial study of the seven heritage churches of the Diocese of Maasin, this paper utilizes only Sevieri et al.’s first level of rapid resistance/vulnerability assessment (Sevieri et al. 2019). Such rapid vulnerability assessments focused on the age of the structures, materials used, histories of degradation, histories of alterations and improvements, and other details that are susceptible to damage, such as roofing systems, windows, doors and other timber work. Actual site visits were done in March of 2019, photographic documentations of the seven structures were done in April 2019, and further visits were done from June to December 2019 and January 2020. 


\section{Multi-Hazard Assessment}

The second cluster of assessments of this paper profiled the extreme natural hazards that threaten these seven heritage churches. Bosher et al. (2019) established that all over the globe, earthquakes, floods, fires, storms and landslides are the top hazards to heritage structures. But because hazards are tightly tied to the specific context of each heritage structure, this paper deviated from this world ranking of hazards and focused instead on storm, flood, storm surge, earthquake, and volcano hazards. Landslide is not a significant hazard for the heritage churches of the Diocese of Maasin as these structures are mostly situated on coastal plains. With Leyte's 22 active and dormant volcanoes, volcanic hazard is significant for these churches. With Leyte's historic experiences of storm surges, such hazards are also significant. Fire hazard is not included in this paper, although it is mentioned by both Bosher et al. and Yu, Oreta, and Ibabao, as it cannot be adequately explored using Sevieri et al.’s first level rapid assessment system (Bosher et al. 2019; Yu et al. 2013; Sevieri et al. 2019).

\section{Storm Hazard}

In profiling the storm hazards, this paper took a different approach from those of Song et al. (2020), Sevieri and Galasso (2020), and Sevieri et al. (2019). As the island of Leyte is located on the eastern part of the Philippine archipelago, its exposure to strong Pacific storms had to be taken as a recurrent threat. Figure 3 presents the pathways of these storms that happened from 1966 to 2016 according to Project NOAH’s “Historical TC Tracks” model.

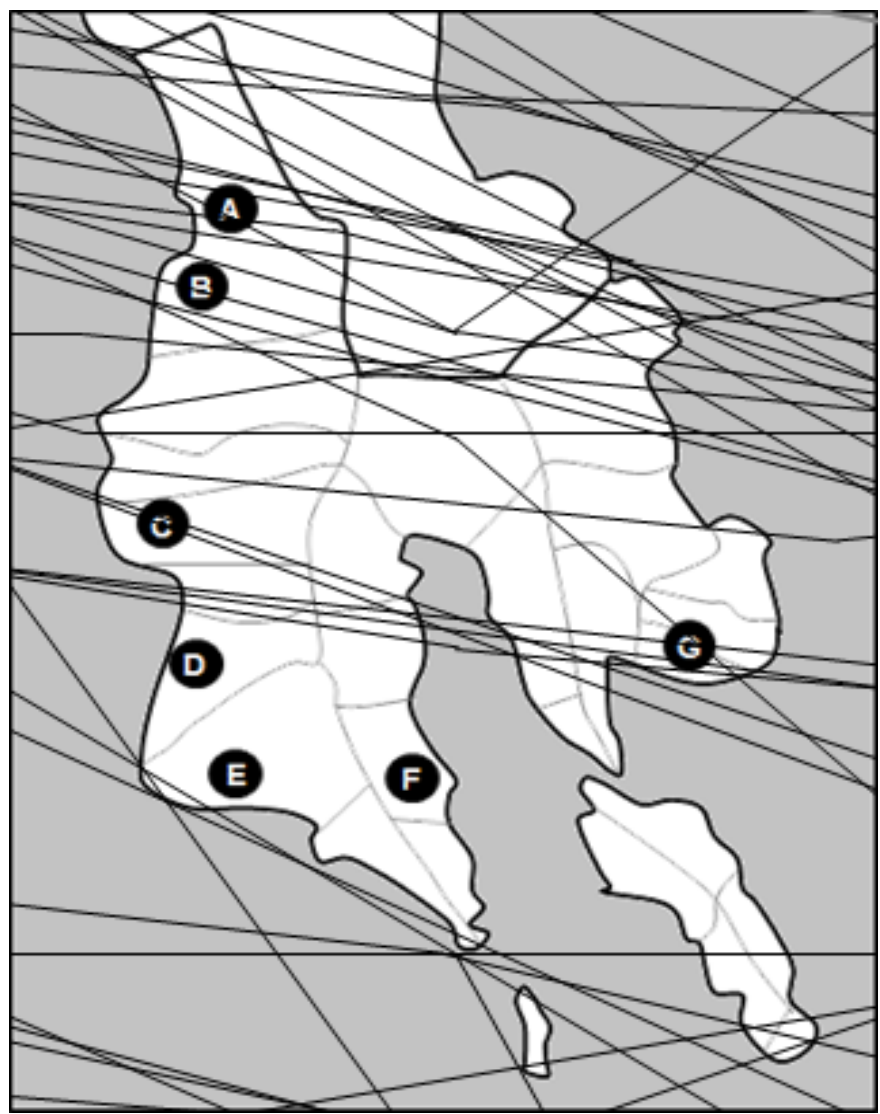

Fig. 3 Pathways of Storms across the Diocese of Maasin from 1966 to 2016 according to the "Historical TC Tracks" Model of Project NOAH. 
Based on the assumption that the whole island of Leyte is recurrently threatened by Pacific storms, this paper reckoned the specific hazard exposure of each of the seven Filipino-Spanish churches relative to their natural geological cover from these weather disturbances coming from the general direction of the east. This was done by pinpointing the location of each of these heritage churches on the map of the island of Leyte from PHIVOLCS' "Fault Finder" application that contains fine details about the elevations of the mountains of the said island. By doing so, this paper can have an estimate on how exposed each of these churches are to the Pacific storms. Table 1 provides the numerical scores and their corresponding verbal interpretations that were used in profiling the hazard.

\begin{tabular}{|l|c|l|}
\hline \multicolumn{1}{|c|}{ Indicators } & Numerical & \multicolumn{1}{c|}{ Verbal } \\
\hline Fully Covered & 1 & Low Hazard \\
\hline Partially Covered & 2 & Medium Hazard \\
\hline Not Covered & 3 & High Hazard \\
\hline
\end{tabular}

Table 1 Numerical Scores and Verbal Interpretations Used for the Churches’ Hazards from Pacific Storms as Mitigated by their Natural Geological Covering.

Flood and Storm Surge Hazards

Following Sevieri et al. (2019), in profiling the flooding and storm surge hazards, the models of Project NOAH were used. Project NOAH is an interactive web application that provides historical and real time information about Philippine natural hazards and weather. It was jointly created by the University of the Philippines Diliman and the Department of Science and Technology of the Republic of the Philippines with the intention of mitigating disasters through educating the Filipinos and providing advanced warning system. More specifically, for flooding, Project NOAH's "100 Year Flood Hazards" model was used; and for storm surge, Project NOAH's "Storm Surge Advisory 1 to 4" models were used. In all of these models, water level is measured as low (presence of water below 0.5 meter), medium ( 0.5 to 1.5 meters), and high (above 1.5 meters). Table 2 provides these measurements with their corresponding numerical and verbal interpretations as used in this paper.

\begin{tabular}{|l|l|c|l|}
\hline \multicolumn{2}{|c|}{ Project NOAH's Measurements } & \multicolumn{2}{c|}{$\begin{array}{c}\text { Scoring and Interpretation } \\
\text { Used by this Paper }\end{array}$} \\
\hline \multicolumn{1}{|c|}{ Verbal } & Measurement & Numerical & \multicolumn{1}{c|}{ Verbal } \\
\hline (No Water) & $(0.0 \mathrm{~m})$ & 0 & Safe \\
\hline Low & up to $0.5 \mathrm{~m}$ & 1 & Low Hazard \\
\hline Medium & 0.5 to $1.5 \mathrm{~m}$ & 2 & Medium Hazard \\
\hline High & $1.5 \mathrm{~m}$ and above & 3 & High Hazard \\
\hline
\end{tabular}

Table 2 Project NOAH's Water Level Measurements and this Paper's Corresponding Numerical Scores and Verbal Interpretations.

\section{Earthquake Hazard}

Building on $\mathrm{Yu}$, Oreta, and Eng's methodology, in profiling the earthquake hazard, three specific approaches were used by this paper (Yu, Oreta, and Eng 2014). First was the location of the seven heritage churches relative to the plot of earthquake epicenters using Project NOAH's "USGS Historical" model as shown in Figure 4. This "USGS Historical" model operates on the data from the United States Geological Survey that recorded at least 3.0 magnitude earthquakes from 1907 to 2017. 


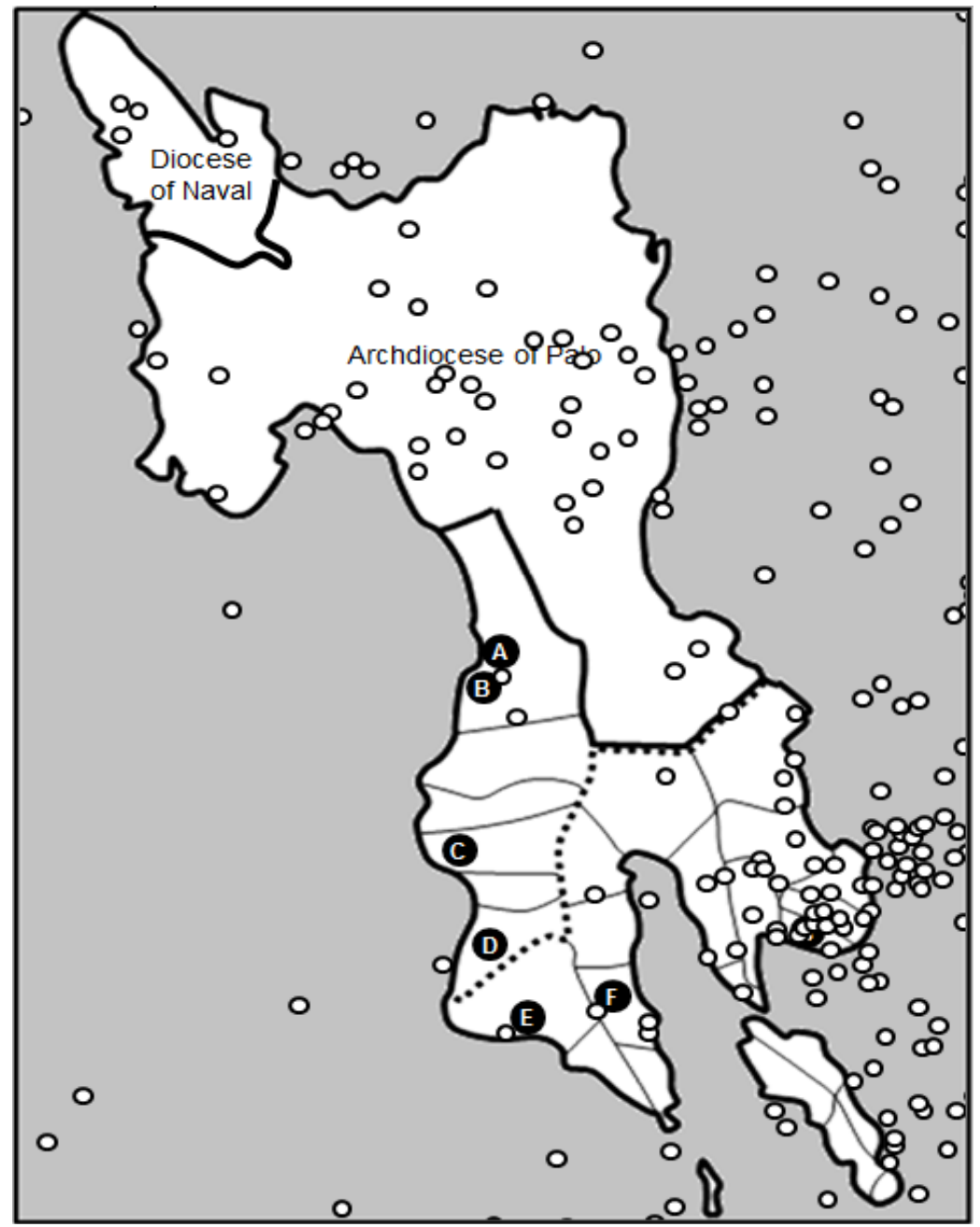

Fig. 4 Approximate Positions of the Seven Filipino-Spanish Churches of the Diocese of Maasin Relative to the Historical Epicenters of Earthquakes in the Island of Leyte according to the "USGS Historical" Model of Project NOAH.

The two general clusters of historical epicenters of earthquakes appear to correlate with the locations of the island's three active and potentially active volcanos, namely: Mount Cabalian, located on the southwestern end of the island of Leyte, Mount Cancajanag, and Mount Mahagnao, located near the middle section of the same island. This first approach was accomplished by visually inspecting whether each of the seven heritage churches are somewhere near to these two discernible clusters of epicenters of historical tremors. Table 3 provides the numerical scores and their corresponding verbal interpretations that were used for this first approach.

\begin{tabular}{|l|c|l|}
\hline \multicolumn{1}{|c|}{ Indicators } & $\begin{array}{c}\text { Numerical } \\
\text { Score }\end{array}$ & \multicolumn{1}{|c|}{ Verbal Interpretation } \\
\hline Very Far from the Clusters & 0 & Safe \\
\hline Far from the Clusters & 1 & Low Hazard \\
\hline Near to the Clusters & 2 & Medium Hazard \\
\hline
\end{tabular}

Table 3 Numerical Scores and Verbal Interpretations Used for the Churches’ Locations Relative to the Clusters of Historical Earthquake Epicenters in the Island of Leyte

The second approach was the calculation of each of the heritage church's nearest distance from the Philippine Fault Line that bisected the island of Leyte, as well as from the North Mindanao Sea 
Fault Line. This was done by using the "Fault Finder" application of the Philippine Institute of Volcanology and Seismology (PHIVOLCS) that automatically plots the shortest distance from any point on its interactive map to the nearest fault line and generates the measurement. Figure 5 shows the approximate positions of the seven heritage churches relative to these fault lines.

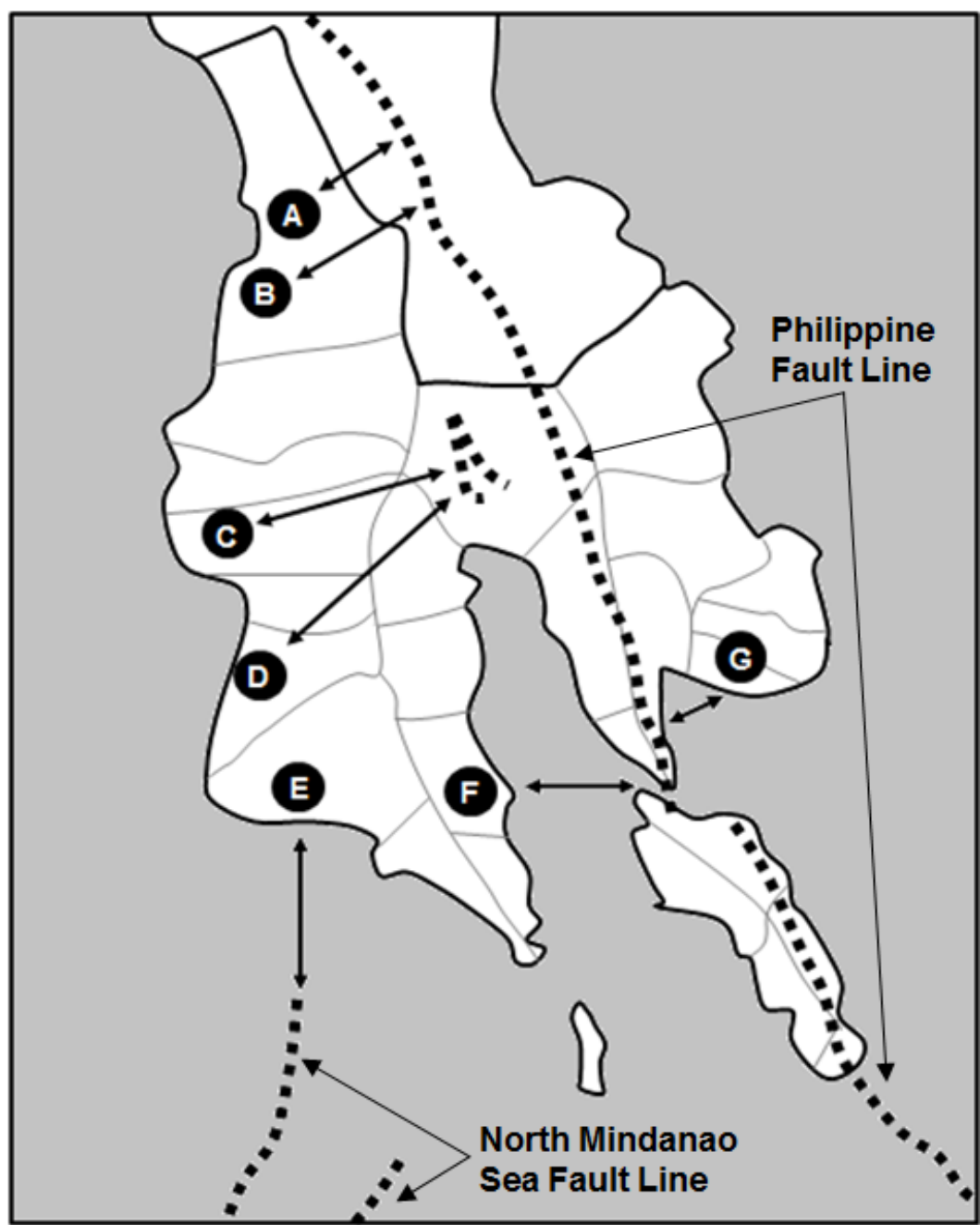

Fig. 5 Approximate Positions of the Seven Filipino-Spanish Churches of the Diocese of Maasin Relative to the Philippine Fault Line and the North Mindanao Sea Fault Line according to the "Fault Finder" Application of PHIVOLCS.

Table 4 provides the numerical scores and their corresponding verbal interpretations that were used for this second approach.

\begin{tabular}{|l|c|l|}
\hline \multicolumn{1}{|c|}{ Indicators } & $\begin{array}{c}\text { Numerical } \\
\text { Score }\end{array}$ & \multicolumn{1}{|c|}{ Verbal Interpretation } \\
\hline Very Far from the Fault Line/s & 0 & Safe \\
\hline Far from the Fault Line/s & 1 & Low Hazard \\
\hline Near to the Fault Line/s & 2 & Medium Hazard \\
\hline Very Near to the Fault Line/s & 3 & High Hazard \\
\hline
\end{tabular}

Table 4 Numerical Scores and Verbal Interpretations Used for the Churches' Locations Relative to the to the Philippine Fault Line and the North Mindanao Sea Fault Line

The third approach was achieved by pinpointing the location of each of the seven heritage churches on the "Ground Shaking Hazard Maps" of Baybay City, Hilongos, Matalom, Maasin City, 
Malitbog, and San Juan as created by the multi-agency Hazard Mapping and Assessment for Effective Community-Based Disaster Risk Management (READY). In these READY maps, hazards are color coded: red for intensity VIII and above on the PHIVOLCS Earthquake Intensity Scale (PEIS), pink for PEIS VII, purple for PEIS VI, and yellow for below PEIS VI. Table 5 provides the numerical scores and their corresponding verbal interpretations that were used for this third approach.

\begin{tabular}{|l|l|c|l|}
\hline \multicolumn{2}{|c|}{ Project READY's Assessments } & \multicolumn{2}{c|}{$\begin{array}{c}\text { Scoring and Interpretation } \\
\text { Used by this Paper }\end{array}$} \\
\hline \multicolumn{1}{|c|}{ Code } & \multicolumn{1}{|c|}{ Assessment } & Numerical & \multicolumn{1}{c|}{ Verbal } \\
\hline (None) & (no tremor) & 0 & Safe \\
\hline Yellow & below PEIS VI & 1 & Low Hazard \\
\hline Purple & PEIS VI & 2 & Medium Hazard \\
\hline Pink & PEIS VII & 3 & High Hazard \\
\hline Red & PEIS VIII and above & 3 & \\
\hline
\end{tabular}

Table 5 Numerical Scores and Verbal Interpretations Used for the Churches’ Positions on the Pertinent READY Project’s “Ground Shaking Hazard Maps”.

Volcanic Hazard

Building on $\mathrm{Yu}$, Oreta, and Eng's methodology for profiling earthquake hazard, in profiling the volcanic hazards for the seven heritage churches, two approaches were used by this paper (Yu, Oreta, and Eng 2014). The first approach involved the pinpointing of the locations of each of the seven heritage structures on "The Ready Project: Volcanic Hazard Map of Leyte” and "The Ready Project: Volcanic Hazard Map of Southern Leyte" as created by the multi-agency READY. In both READY maps, lahar flow hazards are color coded: red for areas that are highly prone to lahar flows, and purple for areas that are moderately prone to lahar flows. Table 6 provides the numerical scores and their corresponding verbal interpretations that were used for the first approach in profiling the volcanic hazard for each of the seven heritage churches.

\begin{tabular}{|l|l|c|l|}
\hline \multicolumn{3}{|c|}{ Project READY's Assessments } & $\begin{array}{c}\text { Scoring and Interpretation } \\
\text { Used by this Paper }\end{array}$ \\
\hline \multicolumn{1}{|c|}{ Code } & \multicolumn{1}{|c|}{ Assessment } & Numerical & \multicolumn{1}{c|}{ Verbal } \\
\hline (None) & (Not Prone to Lahar Flows) & 0 & Safe \\
\hline Purple & Moderately Prone to Lahar Flows & 2 & Medium Hazard \\
\hline Red & Highly Prone to Lahar Flows & 3 & High Hazard \\
\hline
\end{tabular}

Table 6 Numerical Scores and Verbal Interpretations Used for the Churches’ Lahar Flow Hazards.

It must be noted that Project NOAH identifies 21 active and dormant volcanos on the map of the island of Leyte. The same system identifies Mount Cabalian as the only active volcano on the island which is consistent with the data contained in "The Ready Project: Volcanic Hazard Map of Southern Leyte.” Furthermore, Project NOAH identifies Mount Cancanajag as the island's only potentially active volcano, however, this is inconsistent with the data contained in "The Ready Project: Volcanic Hazard Map of Leyte.” In the latter map, no hazards were indicated for the said potentially active volcano. Instead, another active volcano, Mount Mahagnao, is provided with hazard details which is not identified in Project NOAH. Hence, there are at least 22 active and dormant volcanos on the island of Leyte, and the multi-agency READY identifies Mount Cabalian, which had its last eruption in 1820, and Mount Mahagnao, which had its last eruption in 1895, as the sources of hazards near the churches. 
The second approach in profiling the volcanic hazards for the seven heritage churches uses the same "Volcanic Hazard Maps" of the READY Project that also specified which areas of the island of Leyte are prone to pyroclastic flows and surges, coded by golden stripes. Table 7 provides the numerical scores and their corresponding verbal interpretation that was used for this approach.

\begin{tabular}{|l|l|c|l|}
\hline \multicolumn{2}{|c|}{ Project READY's Assessments } & \multicolumn{1}{c|}{$\begin{array}{c}\text { Scoring and Interpretation } \\
\text { Used by this Paper }\end{array}$} \\
\hline Code & Assessment & Numerical & Verbal \\
\hline (None) & (Not Prone to Pyroclastic Flows and Surges) & 0 & Safe \\
\hline Gold Stripes & Prone to Pyroclastic Flows and Surges & 3 & High Hazard \\
\hline
\end{tabular}

Table 7 Numerical Scores and Verbal Interpretations Used for the Churches' Pyroclastic Flow and Surge Hazards

Multi-Hazard Index

In order for the stakeholders to prioritize their conservation efforts a multi-hazard index is created by getting the mean from the storm hazard score, flood hazard score, storm surge hazard score, earthquake hazard score, and volcanic hazard score of each of seven heritage structures.

\section{Multi-Risk Assessment}

Following UNDP's definition of "risks" as the interactions between "natural or human-induced hazards and vulnerable conditions" this paper's profiling of each of the seven heritage churches' multiple risks are based on visualizations on how resistances and vulnerabilities of each church, gathered through rapid assessments, react with the multiple hazards, gathered from available hazard maps and web applications (United Nations Development Programme 2010:1).

\section{Results And Discussions}

\section{Rapid Resistance/Vulnerability Assessments on the Seven Filipino-Spanish Churches}

The reduccion and visita, as a method of setting up towns and parishes, then accessible only through coastal sea travel, resulted to the placement of the existing Filipino-Spanish churches of the Roman Catholic Diocese of Maasin, along the western and southern coastal areas in the island of Leyte, either facing or lying parallel to their respective coastlines. As such, they are safe from landslides but close to the disturbances coming from the coastline. This sub-section presents the comparison between the seven churches based on their age, size, unique features, materials, and techniques used in construction, as well as the various alterations made to them.

Based on Demeterio, Fernandez and Liwanag's book, the oldest among the seven heritage churches is Punta Chapel estimated to have been around for three to four centuries, followed by Hilongos Church which is around two and a half centuries old, Maasin Church which is around two and a quarter centuries old, then by Baybay, Malitbog, and Matalom Churches which are all around one and a half centuries old, and lastly by San Juan Church which is around one and a quarter centuries old (Demeterio et al. 2020: 46, 10, 18, 68, 30, 55, \& 77). Contrary to popular beliefs that FilipinoSpanish churches were constructed by Spanish friars, four of the existing seven churches of the Diocese of Maasin were actually made by Filipino secular priests. In addition to this, the bell tower of Hilongos Church, reputed to be one of the tallest Filipino-Spanish bell towers, was also constructed by a Filipino secular priest. 
Figure 6 presents the rough calculated size of each of the seven Filipino-Spanish churches, based on scaled satellite images from Google Earth, compared to Saint Martin of Tours Basilica, in Taal, Batangas, which is reputed to be the largest church in the Philippines.

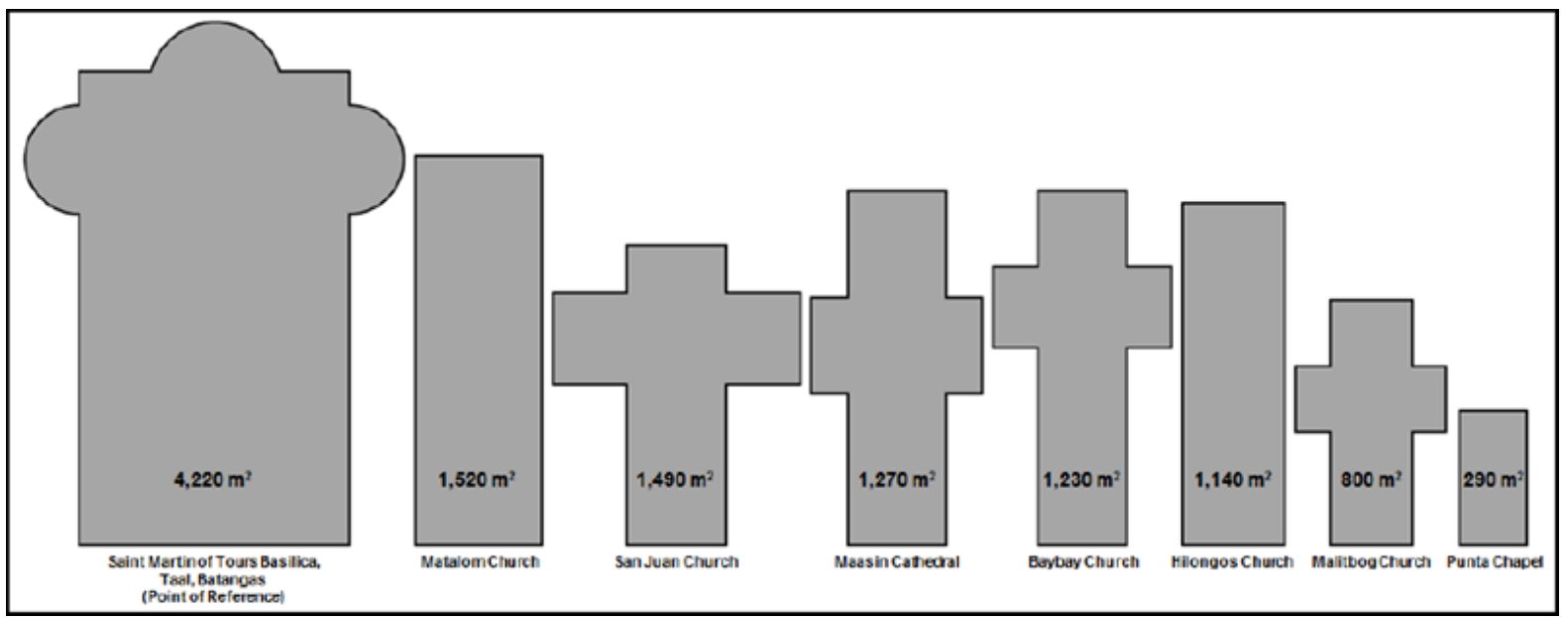

Fig. 6 Rough Calculations of the Sizes of the Seven Filipino-Spanish Churches based on Scaled Satellite Images from Google Earth and Relative to the Size of the Saint Martin of Tours Basilica, Taal, Batangas, the Philippines’ Largest Church.

In Figure 6, Hilongos Church represents its rough size prior to its burning by the Americans in 1901. Hilongos Church is counted as an existing Filipino-Spanish church because its old façade and bell tower are still standing and integrated into the 1968 re-oriented structure. In this paper, San Juan and Matalom Churches are considered relatively large churches; Baybay, Maasin, and Hilongos Churches as relatively medium sized churches; and Malitbog Church and Punta Chapel are considered small churches that are low in height profile compared to the other churches. Aside from its sizes, some notable features for some of the churches were identified. Unique to Hilongos, Maasin, Baybay, and San Juan churches is the presence of buttresses on their walls that add structural stability and support during movement. Another notable feature unique to Baybay, Maasin, and Matalom Churches is the octagonal dome over the crossing between the nave and transepts. Baybay Church has an octagonal wooden dome, while Maasin Church has a semi-circular and bigger dome, but this is covered by a pyramidal roofing system. Malitbog Church has a smaller octagonal dome, with an octagonal lantern that is largely visible from the outside.

In term of materials and methods used in construction, Punta Chapel's side walls had been extended upwards using stone and concrete. Originally, it probably was only about a meter tall, with the remaining height covered with other lighter materials such as the local wattle and daub, called tabique Pampango, or boards, or woven bamboo slats. The load bearing walls of the other six heritage structures are made of rubble and lime mortar construction called mamposteria. Except for the rudimentary stonework of Punta Chapel, all of the other six churches are clad with finely cut coral stones, called cal y canto. Contrary to popular beliefs, these churches are not made of stone blocks, as these visible stones actually look like thick tiles rather than blocks that cover the mamposteria. Figure 7 presents drawings of the façades of these seven heritage churches. 


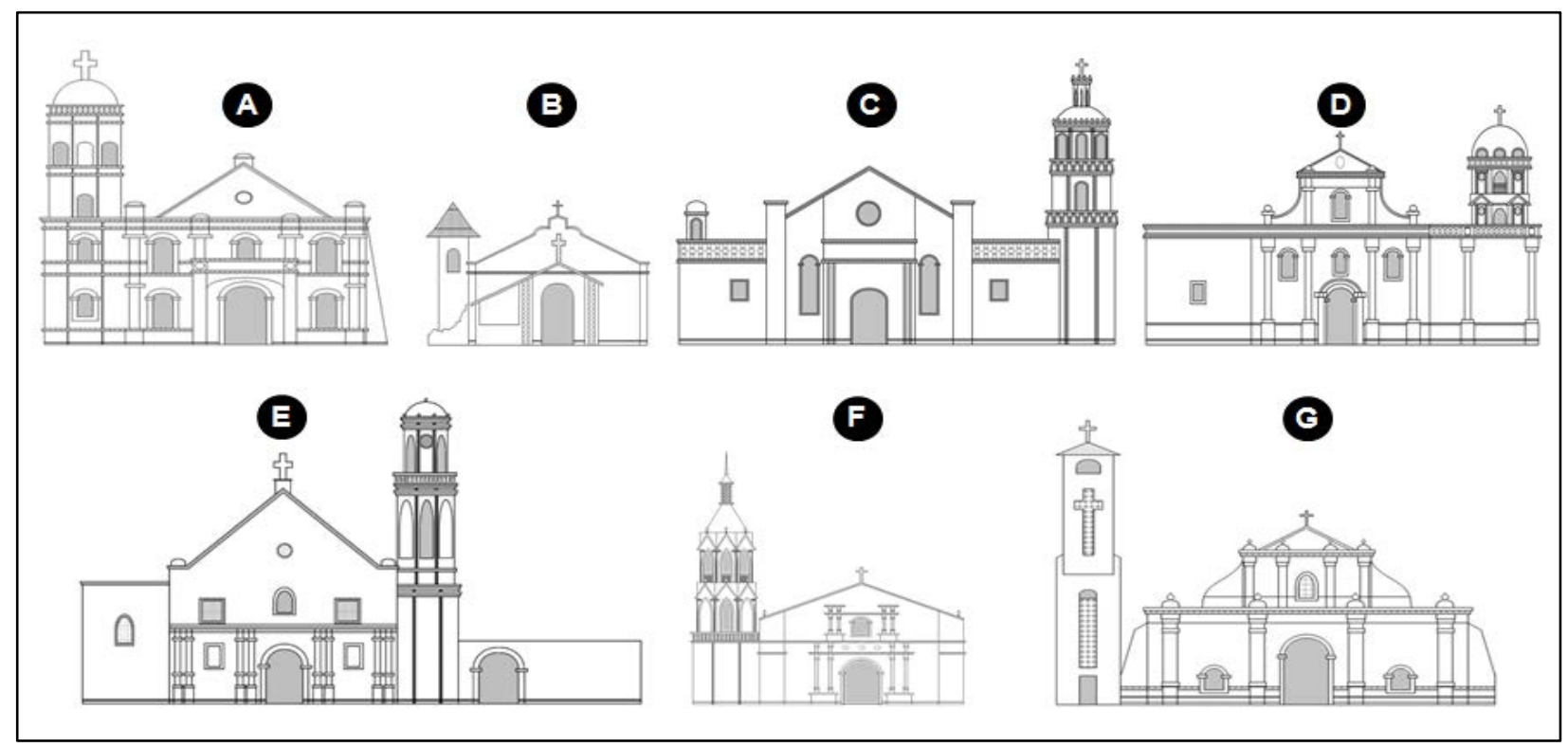

Fig. 7 Drawings of the Façades of (A) Baybay, (B) Punta, (C) Hilongos, (D) Matalom, (E) Maasin, (F) Malitbog, and (G) San Juan Churches.

The bell towers of Maasin, Baybay, and Hilongos Churches, as well as the bases of the bell towers of Malitbog and Matalom Churches are made of the same masonry technique of cladding the mamposteria with cal y canto. Punta Chapel's original bell tower had collapsed many years ago and was replaced by a reinforced concrete structure. It was probably made of mamposteria as suggested by the ruins upon which the present concrete tower stands. The second and third tiers of Malitbog Church's bell tower, including its lantern, are made of wood and are still standing. The original second and third tiers of the Matalom Church's bell tower, including its lantern, were made of wood but were replaced a few decades ago with reinforced concrete. The full five tiers of San Juan Church's bell tower were made of wood but was toppled by a storm about four decades ago and was replaced by an incongruently designed reinforced concrete bell tower.

Majority of the alterations made on these heritage churches was due to the shifting of the colonial influence from Spanish to American as well as the change brought about by the Second Vatican Council which modernized the rituals of the Catholic Church, thus inspiring many Filipino priests to modernize the interiors of their churches. Discernible changes include the removal of the original altar and retablo as evident in the Malitbog church, plastering of interior and/or exterior walls using concrete found in all churches, and the enlargement of windows and doors evident in the Hilongos, Maasin, and Matalom churches. Addition of concrete choir lofts in the Baybay Church, Maasin Church and Malitbog Church was also identified. Some other alterations include the addition of a concrete portico to the façade of Baybay Church some 50 years ago and to Matalom Church entrances, the reorientation of the Hilongos Church using reinforced concrete walls, and extension structures in Malitbog Church made of reinforced concrete. Yet, despite these changes, the Malitbog, Matalom and San Juan churches have retained their old wooden pulpits while Malitbog church has also preserved its wooden retablo. The Maasin church incorporated a new retablo in its church structure as part of its rehabilitation efforts accompanied by the enhancement of the paintings on the church ceilings. All of these churches are now roofed with galvanized iron roofing. However, the original clay tile roofing of the Matalom Church is hidden beneath its current galvanized iron roofing. 


\section{Multi-Hazard Profiling for the Seven Filipino-Spanish Churches}

\section{Storm Hazards}

As mentioned in the methodology of this paper, storm hazards for the seven heritage churches were reckoned by assuming that they are all exposed to the stronger Pacific storms, but such exposures are mitigated by their natural geological covers. Using the elevation data from the "Fault Finder" application of PHIVOLCS, Table 8 examines the natural geological covers of these heritage churches and provides their respected storm hazard numerical scores and verbal interpretations based on Table 1.

\begin{tabular}{|c|c|c|c|c|c|}
\hline Church & $\begin{array}{c}\text { Extent of } \\
\text { Cover }\end{array}$ & Mountain/s & Elevation & $\begin{array}{l}\text { Numerical } \\
\text { Score }\end{array}$ & $\begin{array}{c}\text { Verbal } \\
\text { Interpretation }\end{array}$ \\
\hline \multirow{3}{*}{ Punta } & \multirow{3}{*}{ Full } & $\begin{array}{l}\text { Mountains of Baybay, } \\
\text { Inopacan and Mahaplag }\end{array}$ & $168-867 \mathrm{~m}$ & \multirow{3}{*}{1} & \multirow{3}{*}{ Low Hazard } \\
\hline & & $\begin{array}{l}\text { Mountains of Hindang and } \\
\text { Sogod }\end{array}$ & 405-909 m & & \\
\hline & & $\begin{array}{l}\text { Mountains of Matalom and } \\
\text { Tomas Oppus }\end{array}$ & $143-505 \mathrm{~m}$ & & \\
\hline \multirow{4}{*}{ Hilongos } & \multirow{4}{*}{ Full } & $\begin{array}{l}\text { Mountains of Hilongos and } \\
\text { Bontoc }\end{array}$ & $124-455 \mathrm{~m}$ & \multirow{4}{*}{1} & \multirow{4}{*}{ Low Hazard } \\
\hline & & $\begin{array}{l}\text { Mountains of Matalom and } \\
\text { Tomas Oppus }\end{array}$ & $143-505$ m & & \\
\hline & & $\begin{array}{l}\text { Mountains of Hindang and } \\
\text { Sogod }\end{array}$ & 405-909 m & & \\
\hline & & Mountains of Maasin & $141-674 \mathrm{~m}$ & & \\
\hline \multirow{2}{*}{ Maasin } & \multirow{2}{*}{ Partial } & $\begin{array}{l}\text { Mountains of Macrohon } \\
\text { and Padre Burgos }\end{array}$ & $248-409 \mathrm{~m}$ & \multirow{2}{*}{2} & \multirow{2}{*}{$\begin{array}{l}\text { Medium } \\
\text { Hazard }\end{array}$} \\
\hline & & $\begin{array}{l}\text { Mountains of Maasin and } \\
\text { Malitbog }\end{array}$ & $415-674 \mathrm{~m}$ & & \\
\hline \multirow{2}{*}{ Baybay } & \multirow{2}{*}{ Full } & $\begin{array}{l}\text { Mountains of Baybay, } \\
\text { Inopacan and Mahaplag }\end{array}$ & $168-867 \mathrm{~m}$ & \multirow{2}{*}{1} & \multirow{2}{*}{ Low Hazard } \\
\hline & & $\begin{array}{l}\text { Mountains of Hindang and } \\
\text { Sogod }\end{array}$ & $405-909 \mathrm{~m}$ & & \\
\hline Malitbog & Open & & & 3 & High Hazard \\
\hline \multirow{3}{*}{ Matalom } & \multirow{3}{*}{ Full } & $\begin{array}{l}\text { Mountains of Matalom and } \\
\text { Tomas Oppus }\end{array}$ & $143-505 \mathrm{~m}$ & \multirow{3}{*}{1} & \multirow{3}{*}{ Low Hazard } \\
\hline & & Mountains of Bontoc & $124-231 \mathrm{~m}$ & & \\
\hline & & Mountains of Maasin & $141-674 \mathrm{~m}$ & & \\
\hline San Juan & Partial & $\begin{array}{l}\text { Mountains of San Juan, } \\
\text { Anahawan and } \\
\text { Hinundayan }\end{array}$ & $154-446 \mathrm{~m}$ & 2 & $\begin{array}{l}\text { Medium } \\
\text { Hazard }\end{array}$ \\
\hline
\end{tabular}

Table 8 Pacific Storm Hazards for the Seven Filipino-Spanish Churches of the Diocese of Maasin.

Table 8 shows that Malitbog Church, being directly open to Sogod Bay, has the greatest exposure to storm hazard due to it being in open area, followed by Maasin and San Juan Churches, that are only partly covered by mountains while the other four churches are fully covered by the mountains of the central and southern parts of the island of Leyte.

\section{Flooding Hazards}

Table 9 summarizes the hazards for the seven Filipino-Spanish churches as revealed by the " 100 Year Flood Hazards” model of Project NOAH, and as given their corresponding numerical scoring and verbal interpretation based on Table 2 . 


\begin{tabular}{|l|l|l|c|l|}
\hline \multirow{2}{*}{ Church } & \multicolumn{2}{|c|}{ Project NOAH's Measurements } & \multicolumn{2}{c|}{$\begin{array}{c}\text { Scoring and Interpretation } \\
\text { Used by this Paper }\end{array}$} \\
\cline { 2 - 5 } & Measurement & \multicolumn{1}{|c|}{ Verbal } & Numerical & \multicolumn{1}{c|}{ Verbal } \\
\hline Punta & $(0.0 \mathrm{~m})$ & (No Water) & 0 & Safe \\
\hline Hilongos & $(0.0 \mathrm{~m})$ & (No Water) & 0 & Safe \\
\hline Maasin & $(0.0 \mathrm{~m})$ & (No Water) & 0 & Safe \\
\hline Baybay & up to $0.5 \mathrm{~m}$ & Low Hazard & 1 & Low Hazard \\
\hline Malitbog & $(0.0 \mathrm{~m})$ & (No Water) & 0 & Safe \\
\hline Matalom & 0.5 to $1.5 \mathrm{~m}$ & Medium Hazard & 2 & Medium Hazard \\
\hline San Juan & $(0.0 \mathrm{~m})$ & (No Water) & 0 & Safe \\
\hline
\end{tabular}

Table 9 Hazards for the Seven Filipino-Spanish Churches of the Diocese of Maasin according to the "100 Years Flood Hazards” Model of Project NOAH.

According to the specified model of Project NOAH, the heritage churches are safe from flooding except for Baybay and Matalom Churches that are facing low and medium hazards respectively. Baybay Church's flooding hazard primarily comes from the almost 100 meter-wide Duncaan River that is less than a kilometer northeast of this heritage church. Matalom Church's flooding risk primarily comes from the almost 50 meter-wide Matalom River that is less than a quarter of a kilometer south of this heritage church.

\section{Storm Surge Hazards}

Table 10 summarizes the hazards for the seven Filipino-Spanish churches as revealed by the "Storm Surge Advisory 1 to 4" models of Project NOAH, and as given their corresponding numerical scoring based on Table 2. The composite storm surge hazard was derived from the mean of the numerical scores from the four models.

\begin{tabular}{|c|c|c|c|c|c|c|c|c|c|c|}
\hline \multirow[b]{2}{*}{ Church } & \multicolumn{2}{|c|}{$\begin{array}{c}\text { Storm Surge } \\
\text { Advisory } 1 \\
\end{array}$} & \multicolumn{2}{|c|}{$\begin{array}{l}\text { Storm Surge } \\
\text { Advisory } 2 \\
\end{array}$} & \multicolumn{2}{|c|}{$\begin{array}{c}\text { Storm Surge } \\
\text { Advisory } 3\end{array}$} & \multicolumn{2}{|c|}{$\begin{array}{c}\text { Storm Surge } \\
\text { Advisory } 4 \\
\end{array}$} & \multicolumn{2}{|c|}{$\begin{array}{c}\text { Composite Storm } \\
\text { Surge Hazard } \\
\end{array}$} \\
\hline & 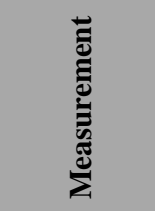 & 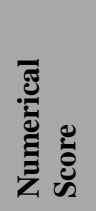 & 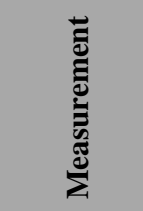 & 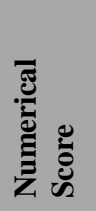 & 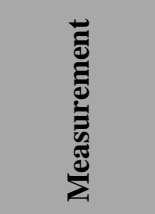 & 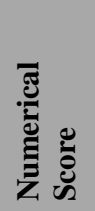 & 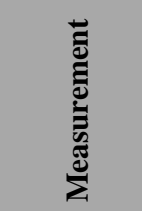 & 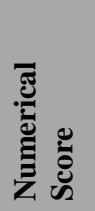 & $\sum_{\Sigma}^{\text {Jँ }}$ & 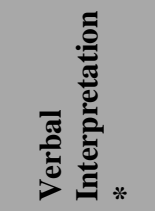 \\
\hline Punta & No Water & 0 & No Water & 0 & No Water & 0 & No Water & 0 & 0.00 & Safe \\
\hline Hilongos & No Water & 0 & $\begin{array}{l}0.5 \text { to } 1.5 \\
\mathrm{~m}\end{array}$ & 2 & $\begin{array}{l}1.5 \mathrm{~m} \& \\
\text { deeper }\end{array}$ & 3 & $\begin{array}{l}1.5 \mathrm{~m} \mathrm{\&} \\
\text { deeper }\end{array}$ & 3 & 2.00 & $\begin{array}{l}\text { Medium } \\
\text { Hazard }\end{array}$ \\
\hline Maasin & No Water & 0 & $\begin{array}{l}0.5 \text { to } 1.5 \\
\mathrm{~m}\end{array}$ & 2 & $\begin{array}{l}1.5 \mathrm{~m} \mathrm{\&} \\
\text { deeper }\end{array}$ & 3 & $\begin{array}{l}1.5 \mathrm{~m} \mathrm{\&} \\
\text { deeper }\end{array}$ & 3 & 2.00 & $\begin{array}{l}\text { Medium } \\
\text { Hazard }\end{array}$ \\
\hline Baybay & $\begin{array}{l}0.5 \text { to } 1.5 \\
\mathrm{~m}\end{array}$ & 2 & $\begin{array}{l}1.5 \mathrm{~m} \mathrm{\&} \\
\text { deeper }\end{array}$ & 3 & $\begin{array}{l}1.5 \mathrm{~m} \mathrm{\&} \\
\text { deeper }\end{array}$ & 3 & $\begin{array}{l}1.5 \mathrm{~m} \mathrm{\&} \\
\text { deeper }\end{array}$ & 3 & 2.75 & $\begin{array}{l}\text { High } \\
\text { Hazard }\end{array}$ \\
\hline Malitbog & No Water & 0 & No Water & 0 & No Water & 0 & $\begin{array}{l}0.5 \text { to } 1.5 \\
\mathrm{~m}\end{array}$ & 2 & 0.50 & Safe \\
\hline Matalom & No Water & 0 & $\begin{array}{l}0.5 \text { to } 1.5 \\
\mathrm{~m}\end{array}$ & 2 & $\begin{array}{l}1.5 \mathrm{~m} \mathrm{\&} \\
\text { deeper }\end{array}$ & 3 & $\begin{array}{l}1.5 \mathrm{~m} \mathrm{\&} \\
\text { deeper }\end{array}$ & 3 & 2.00 & $\begin{array}{l}\text { Medium } \\
\text { Hazard }\end{array}$ \\
\hline San Juan & No Water & 0 & No Water & 0 & No Water & 0 & $\begin{array}{l}\text { up to } 0.5 \\
\text { m }\end{array}$ & 1 & 0.25 & Safe \\
\hline \multicolumn{11}{|c|}{$\begin{array}{l}\text { *Verbal Interpretation of the Mean: } 0.00 \text { to } 0.75 \text {, safe; } 0.76 \text { to } 1.51 \text {, low hazard; } 1.52 \text { to } 2.27 \text {, medium hazard; and } 2.28 \text { to } 3.00 \text {, } \\
\text { high hazard. }\end{array}$} \\
\hline ble 10 & S & & 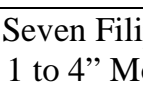 & & Churche & & cese of $\mathrm{M}$ & & & he "Storm \\
\hline
\end{tabular}

According to the composite storm surge hazard scores, Punta, San Juan, and Malitbog Churches are safe from such hazard; Hilongos, Maasin and Matalom Churches are facing medium hazard; while Baybay Church is facing high hazard since of the seven churches, it is situated at just 80 meters 
from its nearest coastline. Although Punta Chapel is a mere 90 meters away to its nearest coastline, this church is planted on a fairly elevated location.

\section{Earthquake Hazards}

As mentioned in the methodology sub-section of this paper, the profiling of the earthquake hazards of the seven heritage churches will be through three different approaches: 1) the location of these seven heritage churches relative to the plot of earthquake epicenters using Project NOAH's "USGS Historical" model; 2) the measuring of the shortest distance from each church to the Philippine Fault Line and to the North Mindanao Fault Line; and 3) the pinpointing of the locations of each of the seven heritage structures on the ground shaking hazard maps of READY.

Historical Epicenters of Earthquakes in the Island of Leyte: Based on Figure 4, Table 11 summarizes the earthquake hazards for the seven heritage churches and their proximity to the clusters of historical epicenters of earthquakes in the island of Leyte, and as given their corresponding numerical scorings and verbal interpretations based on Table 3.

\begin{tabular}{|l|l|c|l|}
\hline \multicolumn{1}{|c|}{ Church } & \multicolumn{1}{c|}{$\begin{array}{c}\text { Findings from Visual } \\
\text { Examination }\end{array}$} & $\begin{array}{c}\text { Numerical } \\
\text { Score }\end{array}$ & Verbal Interpretation \\
\hline Punta & Far from the Clusters & 1 & Low Hazard \\
\hline Hilongos & Far from the Clusters & 1 & Low Hazard \\
\hline Maasin & Far from the Clusters & 1 & Low Hazard \\
\hline Baybay & Far from the Clusters & 1 & Low Hazard \\
\hline Malitbog & Far from the Clusters & 1 & Low Hazard \\
\hline Matalom & Far from the Clusters & 1 & Low Hazard \\
\hline San Juan & Very Near to the Clusters & 3 & High Hazard \\
\hline
\end{tabular}

Table 11 Earthquake Hazards for the Seven Filipino-Spanish Churches of the Diocese of Maasin based on their Locations Relative to the Clusters of Historical Earthquake Epicenters in the Island of Leyte.

As presented in Table 11, only San Juan Church is considered to have high hazard due it its proximity to Mount Cabalian cluster of historical earthquakes while the rest of the churches are considered low hazard since they are far from the two identified clusters.

Distances to the Nearest Points of the Philippine Fault Line: Based on Figure 5, Table 12 summarizes the earthquake hazards for the seven heritage churches and their proximity to the Philippine Fault Line and the North Mindanao Sea Fault Line are concerned, as determined by the "Fault Finder" application of PHIVOLCS, and as given their corresponding findings, numerical scoring and verbal interpretation based on Table 4.

\begin{tabular}{|c|c|c|c|c|c|}
\hline \multirow{2}{*}{ Church } & \multicolumn{2}{|c|}{$\begin{array}{l}\text { Readings from "Fault } \\
\text { Finder" Application }\end{array}$} & \multicolumn{3}{|c|}{$\begin{array}{c}\text { Finding, Scoring and Interpretation Used by this } \\
\text { Paper }\end{array}$} \\
\hline & Distance & $\begin{array}{l}\text { Nearest Fault } \\
\text { Line }\end{array}$ & Finding & Numerical & Verbal \\
\hline Punta & $20.00 \mathrm{~km}$ & Philippine & $\begin{array}{l}\text { Far from the } \\
\text { Fault Line }\end{array}$ & 1 & Low Hazard \\
\hline Hilongos & $26.00 \mathrm{~km}$ & Philippine & $\begin{array}{l}\text { Far from the } \\
\text { Fault Line }\end{array}$ & 1 & Low Hazard \\
\hline Maasin & $18.70 \mathrm{~km}$ & $\begin{array}{l}\text { North } \\
\text { Mindanao Sea }\end{array}$ & $\begin{array}{l}\text { Far from the } \\
\text { Fault Line/s }\end{array}$ & 2 & Medium Hazard \\
\hline Baybay & $15.90 \mathrm{~km}$ & Philippine & $\begin{array}{l}\text { Far from the } \\
\text { Fault Line }\end{array}$ & 1 & Low Hazard \\
\hline Malitbog & $16.10 \mathrm{~km}$ & Philippine & $\begin{array}{l}\text { Far from the } \\
\text { Fault Line/s }\end{array}$ & 2 & Medium Hazard \\
\hline
\end{tabular}




\begin{tabular}{|l|l|l|l|c|l|}
\hline Matalom & $28.00 \mathrm{~km}$ & Philippine & $\begin{array}{l}\text { Far from the } \\
\text { Fault Line/s }\end{array}$ & 2 & Medium Hazard \\
\hline San Juan & $05.20 \mathrm{~km}$ & Philippine & $\begin{array}{l}\text { Very Near to } \\
\text { the Fault Line }\end{array}$ & 3 & High Hazard \\
\hline
\end{tabular}

Table 12 Earthquake Hazards for the Seven Filipino-Spanish Churches of the Diocese of Maasin based on their Locations Relative to the Philippine Fault Line and the North Mindanao Sea Fault Line.

As presented in Table 12, only San Juan Church is categorized with high hazard due to its close proximity to the Philippine Fault Line. Maasin, Malitbog, and Matalom Churches are categorized as medium hazards since these churches are situated between the two mentioned fault lines. The remaining three heritage churches were tagged with low hazard due to them being far from both fault lines.

Locations on the Ground Shaking Hazard Maps: Using the six “Ground Shaking Hazard Maps” from the READY Project, Table 13 summarizes the earthquake hazards for the seven heritage structures, and as given their corresponding numerical scoring and verbal interpretation based on table 5 .

\begin{tabular}{|c|c|c|c|}
\hline Church & $\begin{array}{l}\text { Assessment based on the } \\
\text { READY Project Maps }\end{array}$ & $\begin{array}{c}\text { Numerical } \\
\text { Score }\end{array}$ & $\begin{array}{c}\text { Verbal } \\
\text { Interpretation }\end{array}$ \\
\hline Punta & PEIS VII & 3 & High Hazard \\
\hline Hilongos & PEIS VII & 3 & High Hazard \\
\hline Maasin & PEIS VII & 3 & High Hazard \\
\hline Baybay & PEIS VIII and above & 3 & High Hazard \\
\hline Malitbog & PEIS VII & 3 & High Hazard \\
\hline Matalom & PEIS VII & 3 & High Hazard \\
\hline San Juan & PEIS VIII and above & 3 & High Hazard \\
\hline
\end{tabular}

Table 13 Earthquake Hazards for the Seven Filipino-Spanish Churches of the Diocese of Maasin based on their Locations on the READY Project "Ground Shaking Hazard Maps".

Although only Baybay and San Juan Churches are situated on areas categorized as PEIS VIII and above, all churches were tagged with high hazards since the rest of the churches are in areas categorized as PEIS VII which are already considered destructive. (PHIVOLCS, PHIVOLCS Earthquake Intensity Scale)

Composite Earthquake Hazards: The composite earthquake scores were derived by computing the mean value of the scores from the three approaches as presented in Table 14.

\begin{tabular}{|c|c|c|c|c|c|c|c|c|}
\hline \multirow[b]{2}{*}{ Church } & \multicolumn{2}{|c|}{$\begin{array}{c}\text { Distance to the Clusters } \\
\text { of Historical } \\
\text { Earthquake Epicenters }\end{array}$} & \multicolumn{2}{|c|}{$\begin{array}{c}\text { Distance to the Nearest } \\
\text { Fault Line }\end{array}$} & \multicolumn{2}{|c|}{$\begin{array}{c}\text { Ground Shaking } \\
\text { Hazard }\end{array}$} & \multicolumn{2}{|c|}{ Composite Hazard } \\
\hline & 预 & 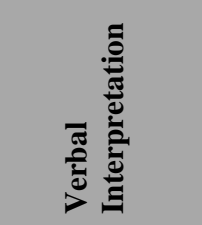 & 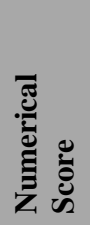 & 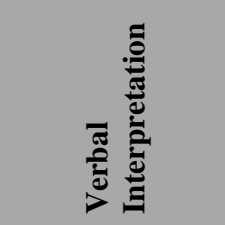 & 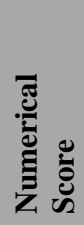 & 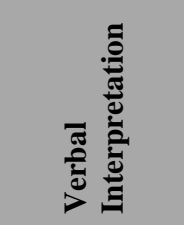 & 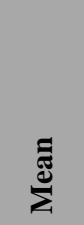 & 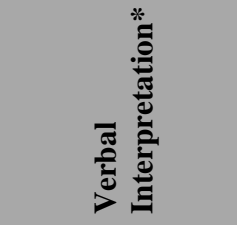 \\
\hline Punta & 1 & Low Hazard & 1 & Low Hazard & 3 & High Hazard & 1.66 & Medium Hazard \\
\hline Hilongos & 1 & Low Hazard & 1 & Low Hazard & 3 & High Hazard & 1.66 & Medium Hazard \\
\hline Maasin & 1 & Low Hazard & 2 & Medium Hazard & 3 & High Hazard & 2.00 & Medium Hazard \\
\hline Baybay & 1 & Low Hazard & 1 & Low Hazard & 3 & High Hazard & 1.66 & Medium Hazard \\
\hline Malitbog & 1 & Low Hazard & 2 & Medium Hazard & 3 & High Hazard & 2.00 & Medium Hazard \\
\hline Matalom & 1 & Low Hazard & 2 & Low Hazard & 3 & High Hazard & 2.00 & Medium Hazard \\
\hline San Juan & 3 & High Hazard & 3 & High Hazard & 3 & High Hazard & 3.00 & High Hazard \\
\hline
\end{tabular}


Table 14 shows that San Juan Church (3.00) has the highest composite earthquake hazard, followed by Maasin (2.00), Malitbog (2.00), and Matalom (2.00) Churches; while Punta (1.66), Hilongos (1.66), and Baybay (1.66) Churches are relatively safer in terms of earthquake hazard.

\section{Volcanic Hazards}

As mentioned in the methodology sub-section of this paper, the volcanic hazard profiling of the seven heritage churches was done through two different approaches: 1) the determination of the churches' exposure to lahar flow hazards; and 2) the determination of the churches' exposure to pyroclastic flow and surge hazards. Both approaches relied on the two "Volcanic Hazard Maps" of the READY Project.

Determination of the Lahar Flow Hazards: Table 15 summarizes the lahar flow hazards for the seven heritage churches, and as given their corresponding numerical scoring and verbal interpretation based on Table 6.

\begin{tabular}{|l|l|l|c|l|}
\hline \multirow{4}{*}{ Church } & \multicolumn{2}{|c|}{$\begin{array}{c}\text { Assessment based on the READY } \\
\text { Project Maps }\end{array}$} & $\begin{array}{c}\text { Scoring and Interpretation } \\
\text { Used by this Paper }\end{array}$ \\
\cline { 2 - 5 } & & & & \\
& & & & \\
& & & & \\
\hline Punta & (None) & (Not Prone) & 0 & Safe \\
\hline Hilongos & (None) & (Not Prone) & 0 & Safe \\
\hline Maasin & (None) & (Not Prone) & 0 & Safe \\
\hline Baybay & (None) & (Not Prone) & 0 & Safe \\
\hline Malitbog & (None) & (Not Prone) & 0 & Safe \\
\hline Matalom & (None) & (Not Prone) & 0 & Safe \\
\hline San Juan & Red & Highly Prone & 3 & High Hazard \\
\hline
\end{tabular}

Table 15 Lahar Flow Hazards for the Seven Filipino-Spanish Churches of the Diocese of Maasin based on the READY Project "Volcanic Hazard Maps”.

Determination of the Pyroclastic Flow and Surge Hazards: Table 16 summarizes the pyroclastic flow and surge hazards for the seven heritage structures, and as given their corresponding numerical scoring and verbal interpretation based on Table 7.

\begin{tabular}{|c|c|c|c|c|}
\hline \multirow[b]{2}{*}{ Church } & \multicolumn{2}{|c|}{$\begin{array}{l}\text { Assessment based on the } \\
\text { READY Project Maps }\end{array}$} & \multicolumn{2}{|c|}{$\begin{array}{c}\text { Scoring and Interpretation } \\
\text { Used by this Paper }\end{array}$} \\
\hline & نु & 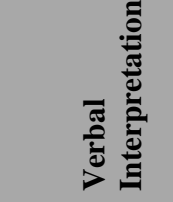 & 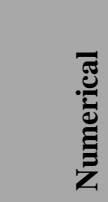 & 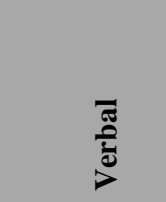 \\
\hline Punta & (None) & (Not Prone) & 0 & Safe \\
\hline Hilongos & (None) & (Not Prone) & 0 & Safe \\
\hline Maasin & (None) & (Not Prone) & 0 & Safe \\
\hline Baybay & (None) & (Not Prone) & 0 & Safe \\
\hline Malitbog & (None) & (Not Prone) & 0 & Safe \\
\hline
\end{tabular}




\begin{tabular}{|l|l|l|l|l|}
\hline Matalom & (None) & (Not Prone) & 0 & Safe \\
\hline San Juan & Gold Stripes & Highly Prone & 3 & High Hazard \\
\hline
\end{tabular}

Table $16 \quad$ Pyroclastic Flow and Surge Hazards for the Seven Filipino-Spanish Churches of the Diocese of Maasin based on the READY Project "Volcanic Hazard Maps".

Composite Volcanic Hazards: By computing the means of the lahar flow hazards and the pyroclastic flow and surge hazards of each of the seven heritage structures, their composite volcanic hazard scores were derived as presented in Table 17.

\begin{tabular}{|c|c|c|c|c|c|c|}
\hline \multirow[b]{2}{*}{ Church } & \multicolumn{2}{|c|}{ Lahar Flow Hazard } & \multicolumn{2}{|c|}{$\begin{array}{c}\text { Pyroclastic Flow and Surges } \\
\text { Hazard }\end{array}$} & \multicolumn{2}{|c|}{ Composite Hazard } \\
\hline & 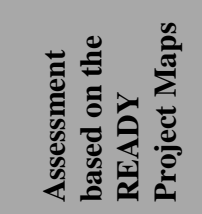 & 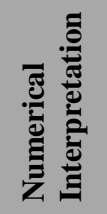 & 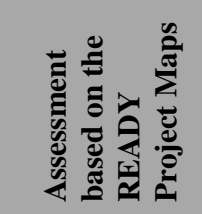 & 预 & 胥 & 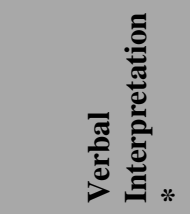 \\
\hline Punta & Safe & 0 & Safe & 0 & 0.00 & Safe \\
\hline Hilongos & Safe & 0 & Safe & 0 & 0.00 & Safe \\
\hline Maasin & Safe & 0 & Safe & 0 & 0.00 & Safe \\
\hline Baybay & Safe & 0 & Safe & 0 & 0.00 & Safe \\
\hline Malitbog & Safe & 0 & Safe & 0 & 0.00 & Safe \\
\hline Matalom & Safe & 0 & Safe & 0 & 0.00 & Safe \\
\hline San Juan & High Hazard & 3 & High Hazard & 3 & 3.00 & High Hazard \\
\hline
\end{tabular}

Table 17 shows that only San Juan Church is exposed to volcanic hazards due to the fact that the church is just about 5 kilometers away from Mount Cabalian.

\section{Multi-Hazard Scores}

By computing the means of the storm, flooding, storm surge, earthquake, and volcanic hazards, the multi-hazard scores for each of the seven heritage structures of the Diocese of Maasin were determined. Table 18 presents these multi-hazard scores.

\begin{tabular}{|c|c|c|c|c|c|c|c|c|c|c|c|c|}
\hline \multirow[b]{2}{*}{ Church } & \multicolumn{2}{|c|}{ Storm Hazard } & \multicolumn{2}{|c|}{$\begin{array}{l}\text { Flooding } \\
\text { Hazard }\end{array}$} & \multicolumn{2}{|c|}{$\begin{array}{c}\text { Storm Surge } \\
\text { Hazard }\end{array}$} & \multicolumn{2}{|c|}{$\begin{array}{c}\text { Earthquake } \\
\text { Hazard }\end{array}$} & \multicolumn{2}{|c|}{$\begin{array}{l}\text { Volcano } \\
\text { Hazard }\end{array}$} & \multicolumn{2}{|c|}{$\begin{array}{l}\text { Multi-Hazard } \\
\text { Score } \\
\end{array}$} \\
\hline & 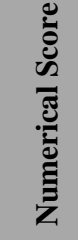 & 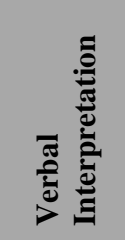 & 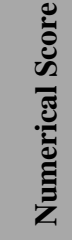 & 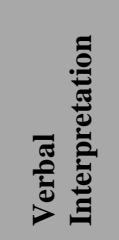 & $\sum^{\text {ङ }}$ & 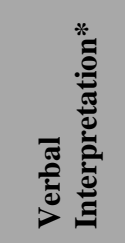 & $\underset{\Xi}{\mathbb{E}}$ & 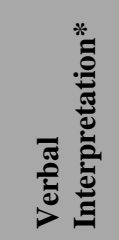 & $\underset{\mathbb{E}}{\stackrel{\Xi}{\Xi}}$ & 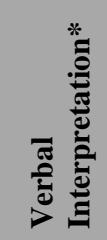 & 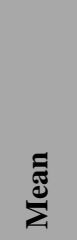 & 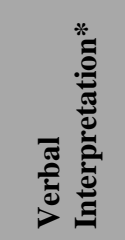 \\
\hline Punta & 1.00 & $\begin{array}{l}\text { Low } \\
\text { Hazard }\end{array}$ & 0.00 & Safe & 0.00 & Safe & 1.66 & $\begin{array}{l}\text { Medium } \\
\text { Hazard } \\
\end{array}$ & 0.00 & Safe & 0.53 & Safe \\
\hline Hilongos & 1.00 & $\begin{array}{l}\text { Low } \\
\text { Hazard } \\
\end{array}$ & 0.00 & Safe & 2.00 & $\begin{array}{l}\text { Medium } \\
\text { Hazard } \\
\end{array}$ & 1.66 & $\begin{array}{l}\text { Medium } \\
\text { Hazard } \\
\end{array}$ & 0.00 & Safe & 0.93 & $\begin{array}{l}\text { Low } \\
\text { Hazard } \\
\end{array}$ \\
\hline Maasin & 2.00 & $\begin{array}{l}\text { Medium } \\
\text { Hazard } \\
\end{array}$ & 0.00 & Safe & 2.00 & $\begin{array}{l}\text { Medium } \\
\text { Hazard } \\
\end{array}$ & 2.00 & $\begin{array}{l}\text { Medium } \\
\text { Hazard } \\
\end{array}$ & 0.00 & Safe & 1.20 & $\begin{array}{l}\text { Low } \\
\text { Hazard }\end{array}$ \\
\hline Baybay & 1.00 & $\begin{array}{l}\text { Low } \\
\text { Hazard } \\
\end{array}$ & 1.00 & $\begin{array}{l}\text { Low } \\
\text { Hazard } \\
\end{array}$ & 2.75 & $\begin{array}{l}\text { High } \\
\text { Hazard }\end{array}$ & 1.66 & $\begin{array}{l}\text { Medium } \\
\text { Hazard } \\
\end{array}$ & 0.00 & Safe & 1.28 & $\begin{array}{l}\text { Low } \\
\text { Hazard } \\
\end{array}$ \\
\hline Malitbog & 3.00 & $\begin{array}{l}\text { High } \\
\text { Hazard }\end{array}$ & 0.00 & Safe & 0.50 & Safe & 2.00 & $\begin{array}{l}\text { Medium } \\
\text { Hazard } \\
\end{array}$ & 0.00 & Safe & 1.10 & $\begin{array}{l}\text { Low } \\
\text { Hazard }\end{array}$ \\
\hline Matalom & 1.00 & $\begin{array}{l}\text { Low } \\
\text { Hazard }\end{array}$ & 2.00 & $\begin{array}{l}\text { Medium } \\
\text { Hazard }\end{array}$ & 2.00 & $\begin{array}{l}\text { Medium } \\
\text { Hazard } \\
\end{array}$ & 2.00 & $\begin{array}{l}\text { Medium } \\
\text { Hazard } \\
\end{array}$ & 0.00 & Safe & 1.40 & $\begin{array}{l}\text { Low } \\
\text { Hazard }\end{array}$ \\
\hline San Juan & 2.00 & $\begin{array}{l}\text { Medium } \\
\text { Hazard }\end{array}$ & 0.00 & Safe & 0.25 & Safe & 3.00 & $\begin{array}{l}\text { High } \\
\text { Hazard }\end{array}$ & 3.00 & $\begin{array}{l}\text { High } \\
\text { Hazard }\end{array}$ & 1.65 & $\begin{array}{l}\text { Medium } \\
\text { Hazard } \\
\end{array}$ \\
\hline
\end{tabular}




\begin{tabular}{|l|l|l|l|l|l|l|l|l|l|l|l|}
\hline Composite & $\mathbf{1 . 5 7}$ & $\begin{array}{l}\text { Low } \\
\text { Hazard }\end{array}$ & $\mathbf{0 . 4 3}$ & Safe & $\mathbf{1 . 3 6}$ & $\begin{array}{l}\text { Low } \\
\text { Hazard }\end{array}$ & $\mathbf{2 . 0 0}$ & $\begin{array}{l}\text { Medium } \\
\text { Hazard }\end{array}$ & $\mathbf{0 . 4 3}$ & Safe & \\
\hline
\end{tabular}
*Verbal Interpretation of the Mean: 0.00 to 0.75, safe; 0.76 to 1.51, low hazard; 1.52 to 2.27, medium hazard; and 2.28 to 3.00,
high hazard.
Table 18

Based on multi-hazard scores, the most threatened structure is San Juan Church (1.65), followed by Matalom Church (1.40), and then by Baybay Church (1.28). The safest of these churches is the Punta Chapel (0.53), followed by Hilongos Church (0.93), and then by Malitbog Church (1.10). Based on the composite score for each hazard, the greatest threat to these heritage churches comes from earthquakes (2.00), followed by storms (1.57), then by storm surges (1.36), while the lowest threat comes from floods (0.43) and volcanoes (0.43).

\section{Multi-Risk Profiling for the Seven Filipino-Spanish Churches}

\section{Punta Chapel}

Based on the findings in the previous section, Punta Chapel is relatively safe from flooding, storm surges and volcanic hazards. However, the church faces medium earthquake hazard where the damage to the original structure may worsen due to the movement of the stone and concrete layer over its much older mamposteria walls as well as the movement of the concrete pediment over the wall on its façade during earth movement events. The church also faces low storm hazards however damages may be minimal due to its low profile and having galvanized iron roofing.

\section{Hilongos Church}

Based on the findings in the previous section, Hilongos Church is relatively safe from flooding and volcanic hazards. However, it faces medium storm surge hazards which threatens to damage the church through rushing waters and debris, especially on the ruins of the old altar and sacristy, and the old façade that faces the coastline. It also faces medium earthquake hazards which may topple the general masonry wall that had experienced fire at the turn of $19^{\text {th }}$ and $20^{\text {th }}$ century, especially on the ruins. The earthquake hazard can also create damages to walls where the old masonry wall and new concrete wall meets, as well as to its lofty bell tower. Low storm hazard will deal minimal damage to the church since its roof has been modified to galvanized iron.

\section{Maasin Church}

Based on the findings in the previous section, Maasin Church is relatively safe from flooding and volcanic hazards. Although it faces medium storm surge hazards which threatens to damage the church through rushing waters and debris, the church might receive minimal to no damage since the wall that faces the coastline is buttressed and as water rushes back to the sea another buttressed wall and the remainder of its fortification will protect it. The church also faces medium earthquake hazards which may heavily damage its general masonry walls that experienced fire during the latter part of the $19^{\text {th }}$ century. Furthermore, it may cause damages to areas where the old masonry was modified, specifically in enlarged windows, added doors, choir loft, and sheds, and to its bell tower that has a slender profile. Low storm hazards might deal minimal damage to the church since the roofing is well maintained and was recently changed to galvanized iron roofing.

\section{Baybay Church}

Based on the findings in the previous section, Baybay Church is only safe from volcanic hazard since the highest peaks of the Leyte Cordillera act as its barrier against the effects of its nearest active volcano, Mount Mahagnao. The heritage church is facing high storm surge hazards due to its 
proximity to the shoreline which might damage the church through rushing waters and debris. The church is, also, facing medium earthquake hazards which might deal heavy damages, specifically where the old masonry walls and the more recent reinforced concrete portico meets, as well as on the window awnings, and the point of contact of the choir loft and the old masonry walls. Furthermore, the earthquake hazard might cause damages to the old bell tower. The church, also, faces low flooding hazards but might only amount to minimal or no damages since the flooding is attributed to the Duncaan river located at a distance. Finally, the church faces low storm hazards but might only yield minimal to no damages since the roof has been renovated to galvanized iron sheets however the paneling and flat galvanized sheets used to cover the exterior of the dome may be damaged during high winds.

\section{Malitbog Church}

Based on the findings in the previous section, Malitbog Church is safe from flooding, storm surge, and volcanic hazards. It is, however, facing high storm hazard, and medium earthquake hazard. The medium earthquake hazard for this heritage structure can create significant damage to its deteriorated wooden bell tower, as well as to its old mortar masonry that were modified to accommodate two additional spaces for the congregation at both sides of the altar as well as a choir loft. The high storm hazard for this church can damage its wooden bell tower as well as the exposed wood and glass components of its dome and lantern. It must be recalled that what toppled the much younger wooden bell tower of San Juan Church was not an earthquake but a Pacific storm.

\section{Matalom Church}

Based on the findings in the previous section, Matalom Church is only safe from volcanic hazard. It faces medium flooding hazard mainly due to its proximity to the Matalom River however might not receive significant damage to its general masonry. The church, also, faces medium storm surge hazard which may damage the masonry walls through rushing waters and debris especially considering that the walls do not have buttresses. The church, also, faces medium earthquake hazard which may incur damages to the un-buttressed walls as well as to the enlarged windows and to the old masonry walls that have direct contact with the reinforced concrete porticos. Earthquakes may send the concealed clay roof tiles down to the floor. Furthermore, the bell tower's second and third levels are also threatened during earthquakes since they are made of reinforced concrete. Finally, the low storm hazard that this church face can cause its galvanized iron roofing sheets flying as they are only layered to the old clay roof tiles, in fact, sections of these roofing sheets are already gone.

\section{San Juan Church}

Based on the findings in the previous section, San Juan Church is safe from flooding and storm surge hazards. It is, however, facing high earthquake and volcanic hazards, and medium storm hazard. The high earthquake hazard for this heritage structure may create damage to its general mortar masonry specially those points that are in contact with the side porticos, niches, and sheds. It is highly possible that the general mortar masonry of this heritage structure would not be able to withstand the threat of lahar flow, and pyroclastic flow and surge from Mount Cabalian. The updated roofing system of this heritage structure may be able to withstand its medium storm hazard, but not possibly a heavy ash accumulation.

\section{Conclusion}

\section{Summation/Conclusion}

This paper revealed that the seven Filipino-Spanish churches of the Roman Catholic Diocese of Maasin have their own distinctive vulnerability and hazard profiles. The multiple disaster risk profiles of each of these seven heritage churches are also distinctive to each of them. However, 
mitigating interventions resulting from common vulnerabilities and hazards can also be identified and implemented to each church. Specific interventions, on the other hand, would require the stakeholders of each church to address the hazards specifically for their church.

\section{Recommendations}

\section{Mitigating Recommendations}

The stakeholders of Punta Chapel may consider taking down the layers of $20^{\text {th }}$ century stone, hollow blocks, and concrete masonry over the old mamposteria and restore the heritage structure to its original, but more stable, composition of some lighter walling, possibly tabique Pampango, over the old mamposteria. The use of concrete plaster that recurs in the other six heritage structures in varying expanse and thickness, can be replaced with lime mortar plastering or more simply with the traditional whitewash of lime, water and animal glue. The stakeholders have to settle whether to recreate the toppled mamposteria bell tower or embrace the present incongruent reinforced concrete bell tower. Churches do change through time with additions and modifications. But in the case of Philippine churches, the shift from Spanish colonial period to American colonial period brought about the radical shift from mortar masonry to reinforced concrete masonry. In instances when the reinforced concrete masonry can endanger the old mortar masonry, it will be easy to say that the older mortar masonry has to be prioritized. But in instances when there is no obvious harm to the latter by the former, the stakeholders really have to soul search on what to do with the $20^{\text {th }}$ century reinforced concrete additions/substitutions. In case the stakeholders of Punta Chapel decide to recreate the toppled mamposteria bell tower, further research is needed on how to do it.

Patrick S. Sparks, in his article “Improving Hurricane Survivability of Heritage Structures,” mentions three ways of protecting heritage structures from storm surges: raising, strengthening, and shielding (Sparks 2010:871-872). Raising may not be an option for the stakeholders of Hilongos Church, but strengthening the free-standing ruins, and shielding both the façade and the freestanding ruins are viable options. Shielding the coastal side of this heritage structure can be a matter of strengthening the existing school buildings and school fence that are located in front of the old facade. Sparks claims that modern buildings of reinforce concrete are already sufficient to slow down the rushing waters and stop the flowing debris during a storm surge (Sparks 2010:871-872). Shielding the other side of the structure can be a matter of strengthening the old fortification of the church. Strengthening the free-standing ruins can be a matter of undoing the niches and holes that were dug out from the old mortar masonry and stabilizing the ruins with steel braces. The stakeholders may consider restoring the original strength and stability of the old façade by undoing the modifications brought about by the enlarged windows. In order to mitigate the destructive reaction to earthquakes along the points where the old masonry meet the new masonry of the additional nave, the stakeholders may consider structurally separating these different materials and filling their gaps with softer plaster that will merely crumble during earthquakes. As to the lofty bell tower of Hilongos Church there is little that can be done except to document it and possibly laser scan it, such that if and when a strong earthquake will topple it down it can be can easily be reconstructed. The stakeholders of Hilongos Church can benchmark on the scientifically engineered reconstruction done on bell tower of the Basilica Minore del Santo Niño de Cebu.

The stakeholders of Maasin Church may consider undoing the modifications on the old mortar masonry brought about by the enlarged windows and additional side doors. The upper levels of the load-bearing walls that were exposed to fire when the heritage structure's roofing system burned at the later part of the 19th century should be tested for signs of weakening. The choir loft and the 
steel sheds may be taken down and replaced with structures that should not be contiguous with the old mortar masonry to avoid damaging such masonry during earthquakes. A similar documentation and laser scanning that were recommended for the Hilongos Church should be done to Maasin Church's slender bell tower. The stakeholders of Maasin Church should make a detailed documentation of the heritage structure's valuable ceiling paintings, in case they will be damaged by earthquake, another fire, or deterioration through time.

The stakeholders of Baybay Church may consider shielding both sides of this heritage structure with specially designed reinforced concrete fences to protect it from storm surges. The reinforced concrete portico that is attached to the façade of this church turned out to be already more than 50 years old. As such it is already considered a heritage structure by itself. To avoid the dilemma of preserving or destroying it, the stakeholders of Baybay Church may modify it by structurally separating it from the façade and by filling the gaps left with softer plaster that will merely crumble during earthquakes. To make this reinforced concrete structure blend with the coral stones of the façade it could be stripped with its paint and just let the bare concrete plaster age. Alternatively, the whole façade and exterior walls can be whitewashed with the traditional lime, water and animal glue formula. The concrete window awnings at the side walls can be replaced with lighter wood and galvanized iron sheets. The concrete choir loft needs to be taken down and replaced with another structure that would not be contiguous with the old mortar masonry of the heritage structure. The cement plastered on the interior walls of the church should also be removed since it brings moist to the old masonry thereby slowly compromising the walls' strength. Further study should be made on the materials of the four great arches under the dome to be able to formulate the most appropriate mitigation against earthquakes. A similar documentation and laser scanning that were recommended for the Hilongos and Maasin Churches should be done to Baybay Church's bell tower. A more aggressive storm proofing should be done to the exposed portions of the exterior dome.

The stakeholders of Malitbog Church may consider repairing and water-proofing its wooden bell tower to make it more capable of withstanding earthquakes, storms, and moisture. In case its repair is not immediately possible, its detailed technical documentation should be undertaken. Laser scanning may not be necessary. The huge punctures at both sides of the altar should be carefully rethought. The stakeholders of Malitbog Church may follow the same recommendation made for the choir lofts of Maasin and Baybay Churches. The church's valuable antique retablo and pulpit should be carefully documented for easier repairs. They may also follow the same recommendation made for the dome of Baybay Church for their own dome and lantern.

The stakeholders of Matalom Church may consider the same recommendations made for Baybay Church in order to protect their heritage structure from the storm surge hazard. These stakeholders need to soul search on whether to maintain their brick tile roofing system or totally replace them with galvanized iron sheets to stabilize the church against earthquake and storm hazards. If they opt to maintain the brick tiles, reinforcements should be made to its roof framing system. These stakeholders may follow the recommendations made for the Baybay Church's portico for Matalom Church's several porticos. Before the reinforced concrete bell tower turns 50 years old, a decision should be made to maintain it or replace it with another one made of wood or maposteria. Documentations should be made on the church's pulpit, confessional box and other hard wood furniture.

The stakeholders of San Juan Church may consider documenting and laser scanning its façade for easier reconstruction if and when it will be toppled down by strong earthquake. Simple photographs 
may not be able to capture its undulating details. The stakeholders may follow the recommendations made for the porticos, concrete awnings and sheds of Maasin, Baybay and Matalom Churches for the porticos, niches and sheds of San Juan Church. There is a need to recheck the load bearing capacity of its roofing system for possible accumulation of volcanic ashes. The stakeholders may follow the recommendations made for the Matalom Church's bell tower for its own bell tower on purely aesthetic grounds, before the San Juan Church’s bell tower turns 50 years old.

\section{Theoretical and Methodological Recommendations}

The simple methodology laid out by this paper can be replicated for heritage structures in almost all parts of the Philippines. Heritage scholars from other countries with enough hazard maps and web applications can also pursue analogous studies. But it has to be remembered that the significant hazards to any given heritage structure is tightly tied to the geographic context of such structure. If human resources, financial support and time would allow, it is advisable to move deeper to the second and third levels of Sevieri et al.’s (2019) rapid assessment of resistance/vulnerability.

\section{Recommendations for Further Research}

Future studies on the seven heritage churches of the Diocese of Maasin should cover fire hazard. These should also factor in the foreseen worsening of hazards brought about by climate change. These should also venture into post-disaster scenarios so that retrieval and recovery plans can be drawn.

\section{Acknowledgements}

This project was made possible by a generous funding from the National Commission for Culture and the Arts of the Republic of the Philippines, with additional support from the De La Salle University and Visayas State University.

\section{References}

Blaire, EH, Robertson, JA and Bourne, EG (1911) Relation of the valorous defense of the Bisayan natives of the village of Palompong, in the island of Leyte, of the province of Catbalogan, in the Philipinas Islands, which they made against the Mahometan forces of Ylanos and Malanaos, in the month of June, 1754. The Philippine islands, 1493-1803: explorations by early navigators, descriptions of the islands and their peoples, their history and records of the Catholic missions, as related in contemporaneous books and manuscripts, showing the political, economic, commercial and religious conditions of those islands from their earliest relations with European nations to the beginning of the nineteenth century. Cleveland, $\mathrm{OH}$ : The Arthur H. Clark Company, 37-51.

Bosher, L, Kim, D, Okubo, T, Chmutina, K and Jigyasu, R (2019) Dealing with multiple hazards and threats on cultural heritage sites: an assessment of 80 case studies. Disaster Prevention and Management, 29(1): 109-128.

Castro, AM (1954) Misioneros agustinos en el Extremo Oriente, 1565-1780: Osario venerable [Augustinian Missionaries in the Far East, 1565-1780: Venerable Ossuary]. Madrid: Consejo Superior de Investigaciones Cientificas, Instituto Santo Toribio de Mogrovejo. D'Ayala, D, Galasso, C, Putrino, V, Zerrudo, E, Manalo, M, Fradiquela, C, Regalado, J, Garciano, L, Oreta, A and Yu, K (2016) Assessment of the Multi-Hazard Vulnerability of Priority Cultural Heritage Structures in the Philippines. Paper presented at 1st International Conference on Natural Hazards \& Infrastructure, 28-30 June, Chania, Greece. 
Demeterio, FPA, Fernandez, GC and Liwanag, LaL (2020) Cataloging \& Baselining the FilipinoSpanish Churches of the Diocese of Maasin on the Island of Leyte. Davao: Aletheia Printing and Publishing House.

Garciano, LE, Campado, DC, Castillo, NA, Odiamar, MG and Tongco, M (2019) Assessment of strength parameters of URM blocks in heritage structures in the Philippines. International Journal of GEOMATE, 17(61): 62-67.

Javellana, RB (1991) Wood and stone for God's greater glory: Jesuit art and architecture in the Philippines. Quezon City: Ateneo de Manila University Press.

Layug, BL (2007) A tourist guide to notable Philippine churches. Quezon City: New Day Publishers.

Mollaneda, RP (1988) A history of a local institution: The church of Baybay. Leyte-Samar Studies, 22: 71-82.

Pearson, L and Pelling, M (2015) The UN Sendai framework for disaster risk reduction 2015-2030: Negotiation process and prospects for science and practice. Journal of Extreme Events, 2(1): 1571001.

Pérez, EJ (1901) Catalogo bio-bibliografico de los religiosos Agustinos de la provincia Del Santisimo nombre de Jésus de las islas Filipinas desde fundación hasta nuestros dias [Biographic and Bibliographic Catalog of Augustinian Friars of the Most Holy Name of Jesus Province in the Philippine Islands from its Foundation to the Present]. Manila: Typographic Establishment of Colegio de Santo Tomas.

PHIVOLCS (n.d.) Fault finder. Available at: http://faultfinder.phivolcs.dost.gov.ph/ [accessed 1115 Aug 2019].

PHIVOLCS (n.d.) PHIVOLCS Earthquake Intensity Scale. Available at: https://www.phivolcs.dost.gov.ph/index.php/earthquake/earthquake-intensity-scale [accessed 11-15 Aug 2019].

Project Noah. (n.d.). Available at: http://noah.up.edu.ph/\#/ [accessed 10-15 Aug 2019].

READY Project (2007) Ground shaking hazard map of Maasin. Available at: https://gisweb.phivolcs.dost.gov.ph/phivolcs_hazardmaps/09.\%20Region\%20VIII/2\%20Pro vince/Southern\%20Leyte/Earthquake/Ground\%20Shaking/2\%20Southern\%20Leyte_Maasi n_GS_2007.png [accessed 12-13 Aug 2019].

Ready Project (2007) Ground shaking hazard map of Malitbog. Available at: https://gisweb.phivolcs.dost.gov.ph/phivolcs_hazardmaps/09.\%20Region\%20VIII/2\%20Pro vince/Southern\%20Leyte/Earthquake/Ground\%20Shaking/2\%20Southern\%20Leyte_Malitb og_GS_2007.png [accessed 12-13 Aug 2019].

READY Project (2007) Ground shaking hazard map of San Juan. Available at: https://gisweb.phivolcs.dost.gov.ph/phivolcs_hazardmaps/09.\%20Region\%20VIII/2\%20Pro vince/Southern\%20Leyte/Earthquake/Ground\%20Shaking/2\%20Southern\%20Leyte_San\%2 0Juan_GS_2007.png [accessed 12-13 Aug 2019].

READY Project (2009) Ground shaking hazard map of Baybay. Available at: https://gisweb.phivolcs.dost.gov.ph/phivolcs_hazardmaps/09.\%20Region\%20VIII/2\%20Pro vince/Leyte/Earthquake/Ground\%20Shaking/2\%20Leyte_Baybay_GS_2010.png [accessed 12-13 Aug 2019].

READY Project (2009) Ground shaking hazard map of Hilongos. Available at: https://gisweb.phivolcs.dost.gov.ph/phivolcs_hazardmaps/09.\%20Region\%20VIII/2\%20Pro vince/Leyte/Earthquake/Ground\%20Shaking/2\%20Leyte_Hilongos_GS_2010.png [accessed 12-13 Aug 2019]. 
READY Project (2009) Ground shaking hazard map of Matalom. Available at:

https://gisweb.phivolcs.dost.gov.ph/phivolcs_hazardmaps/09.\%20Region\%20VIII/2\%20Pro vince/Leyte/Earthquake/Ground\%20Shaking/2\%20Leyte_Matalom_GS_2010.png [accessed 12-13 Aug 2019].

READY Project (2009) Volcanic hazard map of Leyte. Available at: https://pages.rappler.com/preparedness/hazardmaps/Leyte/Provincial/Leyte\%20Volcanic\%20Hazard\%20Map\%20Final.jpg [accessed 1213 Aug 2019].

READY Project (2009) Volcanic hazard map of Southern Leyte. Available at: https://pages.rappler.com/preparedness/hazardmaps/Southern\%20Leyte/Provincial/Southern\%20Leyte\%20Volcanic\%20Hazard\%20Map \%20Final.jpg [accessed 12-13 Aug 2019].

Redondo, FS (1886) Breve reseña de lo que fue y de lo que es la Diócesis de Cebú en las Islas Filipinas [A Brief Survey of What Was and What Is the Diocese of Cebu in the Philippines Island]. Manila: Typographic Establishment of Colegio de Santo Tomas.

Sendai Framework for Disaster Risk Reduction 2015-2030. (2015) Geneva: United Nations Office for Disaster Risk Reduction. Available at:

http://www.wcdrr.org/uploads/Sendai_Framework_for_Disaster_Risk_Reduction_20152030.pdf [accessed 10 August 2019].

Sevieri, G and Galasso, C (2020) Typhoon fragility analysis and climate change impact assessment of Filipino cultural heritage asset roofs. In: M Papadrakakis, M Fragiadakis \& C Papadimitriou, eds). EURODYN 2020: XI International Conference on Structural Dynamics. Proceedings, Volume I, 2020 Athens. European Association for Structural Dynamics (EASD), 4763-4776.

Sevieri, G, Stasio, SD, O’sullivan, K and Galasso, C (2019) The CHeRiSH project: towards a multilevel, multi-hazard risk assessment framework for cultural heritage assets in the Philippines. Paper presented at Atti del XVIII Convegno ANIDIS L’ingegneria Sismica in Italia, 15-19 September, Ascoli Piceno.

Song, B, Galasso, C and Garciano, L (2020) Wind-uplift fragility analysis of roof sheathing for cultural heritage assets in the Philippines. International Journal of Disaster Risk Reduction, 51: 101753.

Sparks, PS (2010) Improving hurricane survivability of heritage structures. Advanced Materials Research, 133-134: 867-872.

Stanton-Geddes, Z, Soz, SA and Bonte-Grapentin, M (2017) Promoting disaster resilient cultural heritage. Washington D.C.: World Bank Group.

United Nations Development Programme (2010) Disaster risk assessment. Available at: https://www.undp.org/content/dam/undp/library/crisis\%20prevention/disaster/2Disaster\%20 Risk\%20Reduction\%20-\%20Risk\%20Assessment.pdf [accessed 10 August 2019].

Yu, K, Oreta, AW and Eng, D (2014) Seismic risk assessment of heritage buildings in Iloilo City, Philippines. Paper presented at the 5th Asia Conference on Earthquake Engineering, October 16-18, Taipei, Taiwan.

Yu, K, Oreta, AW, Ibabao, R and Hechanova, N (2013) Supporting Local Initiatives in Preserving Heritage Buildings in Iloilo City (Philippines) through Risk Assessment. Paper presented at 
the International Conference on Cultural Heritage and Disaster Risk Reduction, November, Bangkok, Thailand. 